\title{
MICROSCOPIC IDENTIFICATION OF FEATHERS AND FEATHER FRAGMENTS OF PALEARCTIC BIRDS
}

\author{
by \\ TIM G. BROM \\ Institute of Taxonomic Zoology (Zoölogisch Museum), University of Amsterdam, \\ P.O. Box 20125, 1000 HC Amsterdam, The Netherlands
}

\begin{abstract}
Using light microscopy, a method has been developed for the identification of feathers and feather fragments collected after collisions between birds and aircraft. Characters of the downy barbules of feathers are described for 22 orders of birds. The use of a key in combination with the macroscopic method of comparing feathers with bird skins in a museum collection results in identification to order or family level in $97 \%$ of the analysed bird strikes. Application of the method to other fields of biological research including taxonomy is discussed.

\section{RÉSUMÉ}

Une méthode utilisant la microscopie optique a été mise à point pour l'identification des plumes et des fragments de plume collectés après des collisions entre oiseaux et avions. On décrit les caractères des barbules duveteuses des plumes pour 22 ordres d'oiseaux. L'utilisation d'une clé en même temps que la comparaison macroscopique des plumes avec des exemplaires de collections muséales, permet dans $97 \%$ des cas de collisions l'identification au niveau de l'ordre ou de la famille. On discute l'application de cette méthode à d'autres domaines de la recherche biologique, y compris la taxonomie.
\end{abstract}

\section{INTRODUCTION}

One of the first steps in solving the problem of collisions between birds and aircraft is establishing which bird species are most accident-prone. During many years, bird strike statistics were based on observations by pilots and ground personnel, and on the occurrence of dead birds found on airfields. Consequently, bird strike statistics were strongly biased by the presence of large and easily recognizable species (Buurma \& Brom, 1979). These, however, do not necessarily constitute the highest risk. So if bird identification is extended beyond macroscopical examination, this would result in a much better assessment of the problem and could suggest the most adequate preventive measures.

LaHam (1967) started the application of microscopic investigation of scrapings collected from engines, combined with the use of amino acid analysis of protein residues, and was able to diagnose bird strikes, so that defective engines rapidly could be separated into those due to either bird strikes or mechanical failures.

The microscopic structure of feathers was first studied by Chandler (1916). He described the structure of pennaceous feathers of North American birds, and found large differences between different taxa. He also examined the downy barbules of a few species and provided evidence that the structure of these barbules is of diagnostic and taxonomic value.

In the present study, the characters of the downy barbules of 350 palearctic species are described.* The results have been applied to the identification of feather fragments collected after collisions between birds and aircraft. About 1400 bird-aircraft incidents have been analysed, which allowed for a statistical evaluation of the groups of birds most often involved in bird strikes (Brom \& Buurma, 1979, 1981; Buurma \& Brom, 1980, 1981; Buurma, 1983; Brom, 1984; Buurma et al., 1984; for literature synopsis see Brom, 1986).

Feather identification is not only important in bird strike analysis, but it has shown to be useful in many areas of study: in forensic science as applied to criminology, food contaminations, and wildlife law enforcement

* A preliminary version of this paper was sent to interested colleagues in many countries (Brom, 1980). 
(Davies, 1970; Deedrick \& Mullery, 1981; Olsen, 1981; Robertson et al., 1984), in archeological work (Hargrave, 1965; Messinger, 1965; Bennike \& Dyck, 1986), and in ecological studies on feeding habits of carnivorous animals (Day, 1966; Altenburg et al., 1982; Astier, 1982; Gilbert \& Nancekivell, 1982).

\section{MATERIAL AND METHODS}

\section{Material}

The examined feathers were taken from freshly dead birds and from specimens in the skin collection of the Zoölogisch Museum Amsterdam (ZMA). No differences in feather structures proved to exist when fresh feathers were compared with feathers from bird skins that had been preserved for many years.

\section{Methods}

The characters examined in this study are found at the downy base (pars plumea) of the contour feathers of a bird (fig. 1). When making preparations, only this part is taken: the downy barbs are cut off close to the shaft of the feather and are sandwiched between an object glass and a cover slip, which are glued together along the edges. This technique is simple and not time-consuming. After initial experiments with embedding substances, mounting the feathers dry under the cover slip turned out to be most appropriate. More contrast is obtained than with the employment of embedding substances which have unsuitable refractive indices.

Dirty or greasy feathers are washed in warm water to which a mild soap or detergent has been added. Then they are rinsed several times in clear water to remove the soap and dried with a hair dryer. Dirty or twisted feathers can usually be restored to their original shape by this procedure. Different feathers require somewhat different techniques of drying. Feathers with long and lax barbules (such as those of owls and other birds of prey) are more difficult to blow out as their tips tend to become tangled, whereas feathers from birds like waterfowl fluff up readily.

The feather structures were studied by light microscopy using magnifications between 50 and $500 \times$.

\section{DESCRIPTION OF CHARACTERS}

A feather is composed of three elements: the axis, the barbs, and the barbules. The proximal part of a feather, the calamus, is fixed in the skin of the bird. From the distal part, called the shaft or rachis, barbs are branching off on both sides to form the outer and inner vanes. From these barbs, barbules are branching off to form the outer and inner vanules. The basal part of the vanes is more (in body feathers) or less (in flight feathers) downy in character.

The downy barbules consist of a base and a pennulum, and it is here that we find the features on which many taxa of birds, sometimes down to species level, can be distinguished. The following characters are used in identification:

1. The borders of the cells forming the pennulae are often swollen or show prongs. In this way, the barbules are divided into nodes and internodes, clearly visible at lower magnifications. Nodes vary in shape from round to heart-shaped to elongated and may be more or less strongly pigmented. Prongs vary in length and curvature. Collectively nodes and prongs are called nodal structures.

2. Nodal structures may be uniformly distributed along the entire length of the barbule or found only at its base or tip.

3 . The basal cells by which the barbules are attached to the barbs may show villi (outgrowths).

4. The length of the barbules as well as the number of nodal structures per $\mathrm{mm}$ are distinctive for certain groups. Whenever possible, the nodal structures have been counted (at magnification of $50 x$ ) and their number per $\mathrm{mm}$ of barbule is given.

The intraspecific variability of these characters was examined before differences between higher taxa of birds were described.

a. Topical variation: Of five species (Blackheaded Gull Larus ridibundus, Lapwing Vanellus vanellus, Oystercatcher Haematopus ostralegus, Chaffinch Fringilla coelebs, and Skylark Alauda arvensis) an extensive series of feather preparations (taken from 26 different feathers from each specimen) was examined in order to determine the variation within an individual plumage. Considerable differences proved to exist in degree of pigmentation, number of nodal structures per $\mathbf{m m}$ of barbule, and length of the barbules. The 
following feather regions have been found to cover the whole range of variation within one bird: breast, belly, under tail coverts, upper tail coverts, mantle, and upper wing coverts. In case of a bird strike it is usually not known from which part of the bird a feather originates. So, in the tables only ranges are given (instead of averages) for number of nodes per $\mathrm{mm}$ and for length of barbule. In all species a feather was studied from each of the six regions mentioned above. From each feather at least 5 barbules were measured and counted for nodal structures, so the given ranges result from about 30 measurements and counts for each species.

b. Individual variation: Feathers from two individuals of the same species have been compared to establish the degree of individual variation. This was done for Black-headed Gull Larus ridibundus, Goosander Mergus merganser, Swift Apus apus, and Secretary Bird Sagittarius serpentarius. No intraspecific variation was found.

c. Sexual variation: In two species (Lapwing Vanellus vanellus and Red-footed Falcon Falco vespertinus) feathers from both sexes have been compared. Even in the highly dimorphic Red-footed Falcon no differences were found.

d. Variation with age and time of the year: Barbules from juvenile and adult plumage were compared for Goshawk Accipiter gentilis, Black-headed Gull Larus ridibundus, Meadow Pipit Anthus pratensis, and Greenfinch Carduelis chloris. Nestlings and fledglings differ from older birds because the downy barbules, if present, are simple and not fully developed. In a fully developed juvenile plumage, however, the size and structure of the downy barbules is indistinguishable from the adult.

No variation with the time of the year was found. As the examined barbules are the most basal ones of the feather, located close to the skin, they are not as much subject to wear as is the plumage in general.

\section{DESCRIPTION OF ORDERS}

The description of bird species follows the taxonomic sequence as given by Voous (1973, 1977).

In addition to a description of the structure of their downy barbules, information on the weights of the different species has been included, as weight is a key factor in the analysis of bird strikes (Buurma, 1984). This information was mainly taken from Cramp \& Simmons (1977, 1980, 1983), Brough (1983), and Cramp (1985), and from collection files in the Zoölogisch Museum Amsterdam.

\section{Gavirformes (fig. 2 ; table I)}

This order consists of a single family (Gaviidae). All species have been examined. Range of weights 800-6400 g.

Description. - The barbules are extremely short (0.5-1.1 mm). At low magnification they appear filamentous, not pigmented. They possess prongs, most conspicuously at their tips. A subdivision of the barbules is perceptible, but no enlarged nodes are present. No villi at the basal cells.

TABLE I

Body weight (in $\mathrm{g}$ ) and length of barbules (in $\mathrm{mm}$ ) in Gaviiformes.

\begin{tabular}{llrr}
\hline Species & & \multicolumn{1}{c}{$\begin{array}{c}\text { body } \\
\text { weight }\end{array}$} & \multicolumn{1}{c}{$\begin{array}{c}\text { barbule } \\
\text { length }\end{array}$} \\
\hline Gavia stellata & Red-throated Diver & $800-2460$ & $0.5-0.9$ \\
G. arctica & Black-throated Diver & $1200-3792$ & $0.5-1.0$ \\
G. immer & Great Northern Diver & $2200-4480$ & $0.7-1.1$ \\
G. adamsii & White-billed Diver & $3700-6400$ & $0.8-1.1$ \\
\hline
\end{tabular}

\section{Podicipediformes (fig. 3 ; table II)}

This order consists of a single family (Podicipedidae). Five species have been examined. Range of weights 91-1490 g.

Description. - The barbules are on average longer $(0.7-1.7 \mathrm{~mm})$ than in Gaviiformes. 

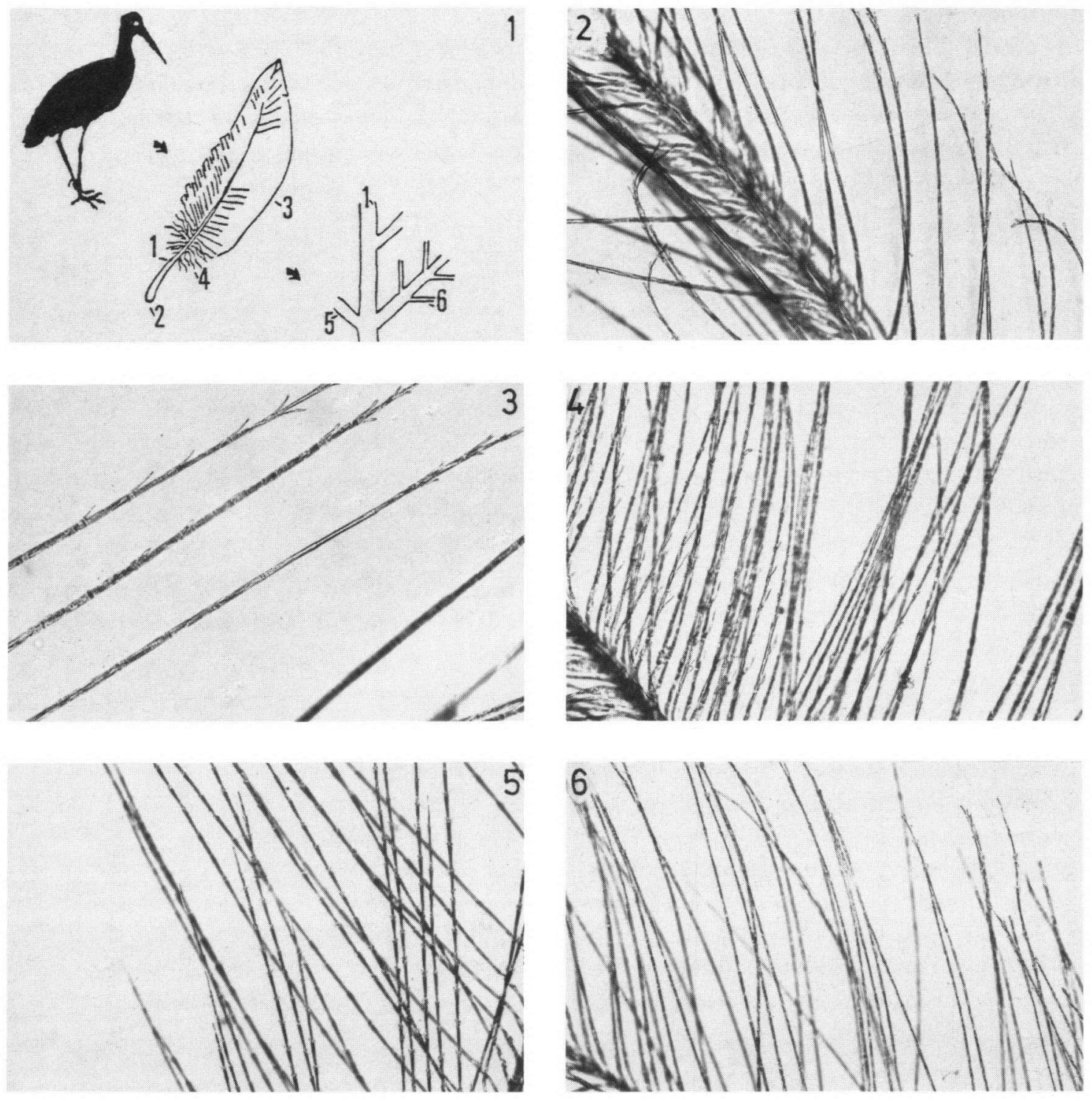

Fig. 1. Position of the downy barbules that are described in this paper: $1=$ shaft or rachis, $2=$ calamus, $3=$ vane 4 = downy part of feather (pars plumea), 5 = barb, $6=$ barbule.

Fig. 2. Black-throated Diver Gavia arctica; breast feather $(105 \times)$.

Fig. 3. Black-necked Grebe Podiceps nigricollis; belly feather $(165 \times)$.

Fig. 4. Cory's Shearwater Calonectris diomedea; mantle feather $(105 \times)$.

Fig. 5. Leach's Storm Petrel Oceanodroma leucorhoa; mantle feather $(105 \times)$.

Fig. 6. Great Cormorant Phalacrocorax carbo; upper tail covert $(105 \times)$.

Prongs are always present at the tips and in this respect grebes may resemble Anseriformes, but triangular nodes are not present. Proximally, a subdivision of the barbules is perceptible, usually indicated by prongs present at only one side of the barbule, but nodes cannot be counted. No villi at the basal cells.
3. Procellarifformes (figs. $4-5$; table III)

Five species from two families (Procellariidae and Hydrobatidae) have been examined. Range of weights $18-1130 \mathrm{~g}$.

Description. - The barbules are extremely short $(0.5-1.1 \mathrm{~mm})$, and a subdivision into 
TABLE II

Body weight (in $\mathrm{g}$ ) and length of barbules (in $\mathrm{mm}$ ) in Podicipediformes.

\begin{tabular}{llcc}
\hline Species & & $\begin{array}{c}\text { body } \\
\text { weight }\end{array}$ & $\begin{array}{c}\text { barbule } \\
\text { length }\end{array}$ \\
\hline $\begin{array}{l}\text { Tachybaptes } \\
\quad \text { ruficollis }\end{array}$ & Little Grebe & $91-315$ & $0.7-1.3$ \\
Podiceps cristatus & Great Crested Grebe & $492-1490$ & $0.7-1.5$ \\
$P$. grisegena & Red-necked Grebe & $316-1270$ & $0.7-1.4$ \\
$P$. auritius & Slavonian Grebe & $300-500$ & $0.7-1.6$ \\
$P$. nigricollis & Black-necked Grebe & $213-450$ & $0.7-1.7$ \\
\hline
\end{tabular}

slightly swollen nodes or well-developed prongs (21-29 per $\mathrm{mm}$ ) and internodes is easily perceptible. Usually the nodes are not pigmented, except in Oceanodroma leucorhoa and often in Hydrobates pelagicus. No villi at the basal cells.

TABLE III

Body weight (in $\mathrm{g}$ ), length of barbules (in $\mathrm{mm}$ ), and number of nodal structures (per mm barbule) in Procellariiformes.

\begin{tabular}{|c|c|c|c|c|}
\hline Species & & $\begin{array}{l}\text { body } \\
\text { weight }\end{array}$ & $\begin{array}{l}\text { barbule } \\
\text { length }\end{array}$ & $\begin{array}{c}N \text { of } \\
\text { nodes }\end{array}$ \\
\hline Fulmarus glacialis & Northern Fulmar & $535-1000$ & $0.7-1.1$ & $25-29$ \\
\hline Calonectris diomedea & Cory's Shearwater & $500-1130$ & $0.6-1.0$ & $21-26$ \\
\hline Puffinus puffinus & Manx Shearwater & $310-565$ & $0.6-1.0$ & $22-27$ \\
\hline Hydrobates pelagicus & Storm Petrel & $18-40$ & $0.5-1.1$ & $24-29$ \\
\hline Oceanodroma & Leach's Storm & & & \\
\hline leucorhoa & Petrel & $29-57$ & $0.5-1.0$ & $23-27$ \\
\hline
\end{tabular}

\section{Pelecaniformes (figs. 6-7; table IV)}

Six species from five families (Phaethontidae, Sulidae, Phalacrocoracidae, Pelecanidae, and Fregatidae) have been examined. Range of weights 427-13000 g.

Description. - The barbules are short (0.5$1.5 \mathrm{~mm}$ ) and smoothly filamentous for most of their length. No villi at the basal cells. In pigmentation of the pennulae and in length of the prongs some variation exists within this order.

Pelecanidae and Fregatidae: The barbules are not pigmented and no swollen nodes are found. At the tips there are minute prongs which sometimes extend along the whole length of the barbule.
Phalacrocoracidae: The barbules are usually not pigmented; sometimes a diffuse pigmentation is visible which gives the impression of a subdivision of the barbules, but nodal structures could not be counted. At the tips there are always some minute prongs, which often are only perceptible at higher magnifications; occasionally the prongs extend along the entire length of the barbule.

Sulidae: The barbules are not pigmented, but they possess many very well-developed prongs along their entire length. These prongs reach a length of over $0.1 \mathrm{~mm}$ and they are always longer than the adjacent internodes. They are slender, filamentous, and frequently bifurcated, and they only slightly decrease in length towards the tips of the barbules.

Phaethontidae: The barbules are not pigmented and possess short prongs along their entire length (21-25 per $\mathrm{mm}$ ).

\section{TABLE IV}

Body weight (in $\mathrm{g}$ ) and length of barbules (in $\mathrm{mm}$ ) in Pelecaniformes.

\begin{tabular}{|c|c|c|c|}
\hline Species & & $\begin{array}{c}\text { body } \\
\text { weight }\end{array}$ & $\begin{array}{l}\text { barbule } \\
\text { length }\end{array}$ \\
\hline $\begin{array}{l}\text { Phaethon } \\
\text { aethereus }\end{array}$ & $\begin{array}{l}\text { Red-billed } \\
\text { Tropicbird }\end{array}$ & $427-730$ & $0.6-1.0$ \\
\hline $\begin{array}{l}\text { Sula bassana } \\
\text { Phalacrocorax }\end{array}$ & Northern Gannet & $1630-3610$ & $0.5-1.0$ \\
\hline carbo & Great Cormorant & $1500-4900$ & $0.7-1.2$ \\
\hline$P$. aristotelis & Shag & $1470-2154$ & $0.6-1.2$ \\
\hline $\begin{array}{c}\text { Pelecanus con- } \\
\text { spicillatus }\end{array}$ & $\begin{array}{c}\text { Australian } \\
\text { Pelican }\end{array}$ & $4000-13000$ & $0.7-1.3$ \\
\hline $\begin{array}{l}\text { Fregata } \\
\quad \text { magnificens }\end{array}$ & $\begin{array}{l}\text { Magnificent } \\
\text { Frigatebird }\end{array}$ & $1061-1750$ & $0.9-1.5$ \\
\hline
\end{tabular}

\section{Ciconilformes (figs. 8-10; table V)}

Thirteen species from three families (Ardeidae, Ciconiidae, and Threskiornithidae) have been examined. Range of weights $64-5000 \mathrm{~g}$.

Description. - The barbules vary in length from 0.8 to $3.0 \mathrm{~mm}$. Some differences exist between the families examined, in the length of the barbules, degree of pigmentation, presence of prongs, and number of nodal structures per $\mathrm{mm}$. No villi at the basal cells. 
Ciconiidae: The barbules are rather long $(1.2-2.5 \mathrm{~mm})$, slender, filamentous and not pigmented. Usually there are small, inconspicuous prongs along the entire length of the barbule (11-14 per $\mathrm{mm}$ ), which are fewer in number than in both other families.

Ardeidae: The barbules are rather long (1.1$3.0 \mathrm{~mm}$ ), very slender, filamentous, with slightly enlarged nodal structures which can often be counted. In Bubulcus, Ardeola, Egretta, and Nycticorax the barbules are not pigmented, and some minute prongs can be found. In Ardea, Botaurus, and Ixobrychus the barbules may be uniformly (or almost uniformly) pigmented (pigment not collected into conspicuous spots) or not pigmented, with minute prongs usually present only distally.

\section{TABLE V}

Body weight (in g) and length of barbules (in $\mathrm{mm}$ ) in Ciconiiformes.

\begin{tabular}{|c|c|c|c|}
\hline Species & & $\begin{array}{c}\text { body } \\
\text { weight }\end{array}$ & $\begin{array}{c}\text { barbule } \\
\text { length }\end{array}$ \\
\hline Botaurus stellaris & Bittern & $430-1940$ & $1.3-2.0$ \\
\hline \multicolumn{4}{|c|}{ Ixobrychus } \\
\hline minutus & Little Bittern & $64-170$ & $1.6-2.1$ \\
\hline \multicolumn{4}{|l|}{ Nycticorax } \\
\hline nycticorax & Night Heron & $339-1014$ & $1.2-2.1$ \\
\hline Ardeola ralloides & Squacco Heron & $180-370$ & $1.1-2.2$ \\
\hline Bubulcus ibis & Cattle Egret & $300-450$ & $1.3-2.4$ \\
\hline Egretta garzetta & Little Egret & $280-614$ & $1.1-1.9$ \\
\hline \multirow[t]{2}{*}{ E. alba } & Great White & & \\
\hline & Egret & $760-1680$ & $1.2-3.0$ \\
\hline Ardea cinerea & Grey Heron & $810-2300$ & $1.2-2.5$ \\
\hline A. purpurea & Purple Heron & $515-1650$ & $1.2-2.5$ \\
\hline Ciconia nigra & Black Stork & $2400-3000$ & $1.2-2.1$ \\
\hline C. ciconia & White Stork & $2140-5000$ & $1.3-2.5$ \\
\hline \multicolumn{4}{|l|}{ Plegadis } \\
\hline falcinellus & Glossy Ibis & $365-850$ & $0.8-1.2$ \\
\hline \multicolumn{4}{|l|}{ Platalea } \\
\hline leucorodia & Spoonbill & $795-1960$ & $0.9-1.3$ \\
\hline
\end{tabular}

Threskiornithidae: The barbules are shorter than in both other families $(0.8-1.3 \mathrm{~mm})$, stout and coarse, and they are not pigmented. Along their entire length the barbules possess welldeveloped prongs (19-23 per mm in Platalea and 21-26 in Plegadis), which are always shorter than the adjacent internodes. The nodal structures are more numerous per $\mathrm{mm}$ than in both other families.

\section{Phoenicopteriformes (fig. 11)}

This order consists of a single family (Phoenicopteridae). Two species have been examined: Greater Flamingo Phoenicopterus ruber and Lesser Flamingo $P$. minor. Range of weights $1412-4400 \mathrm{~g}$.

Description. - The barbules are very short (0.5-1.2 $\mathrm{mm})$ and not pigmented. Along their entire length small sprongs are found (22-27 per $\mathrm{mm})$, that are slightly longer than in Ciconiiformes. Only distally some slightly enlarged nodes may be present. No villi at the basal cells.

\section{ANSERIformes (figs. 12-14; table VI)}

Thirty-eight species of the family Anatidae have been examined. Range of weights 163$15000 \mathrm{~g}$.

Description. - The barbules are rather short $(0.5-2.0 \mathrm{~mm}$, but usually less than 1.3 $\mathrm{mm}$ ) and simple in structure. For the greater part of their length they are thread-like. The nodes are undeveloped except at the distal part of the barbule where a number of triangular (but visible as heart-shaped under the microscope) nodes are found, followed by a slender tip. The number of terminal nodes may differ considerably (from 1 to 10 ) in different genera, but no diagnostic value resides in this character as large differences can be found between feathers of a single bird. The nodes may sometimes be reduced and in that case a few terminal pairs of prongs are taking their place. Pigmentation of the barbules is confined to the nodes and varies in density from species to species. The internodes are long (longer in geese than in ducks) and often show a conspicuous bending or kinking, usually most pronounced in geese. No significant differences are found in the length of the barbules of the various species. However, three large groups can be distinguished when the part of the barbule is measured that shows nodal structures. 

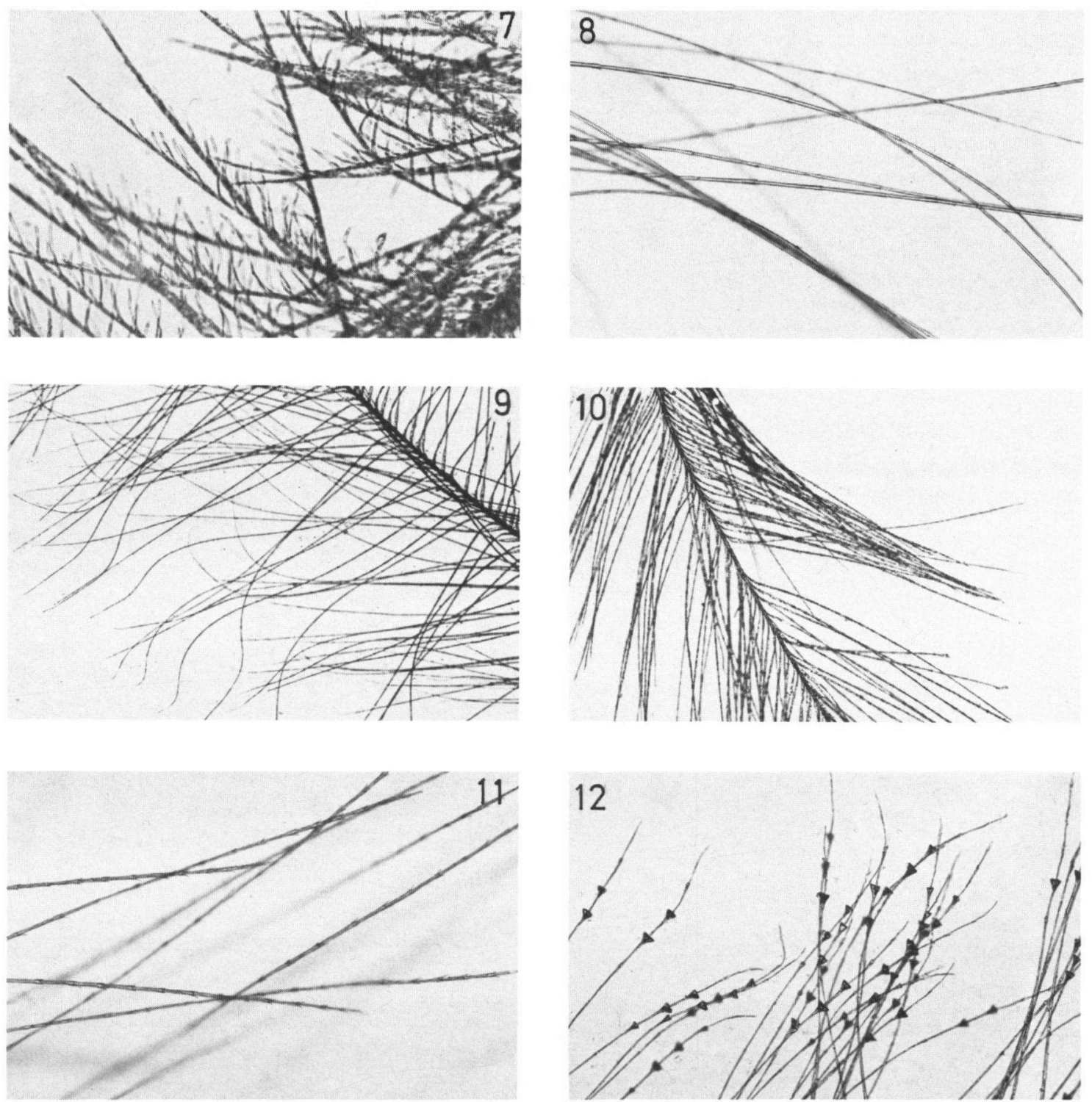

Fig. 7. Northern Gannet Sula bassana; throat feather $(105 x)$.

Fig. 8. White Stork Ciconia ciconia; under tail covert $(105 \times)$.

Fig. 9. Bittern Botaurus stellaris; under wing covert $(42 \times)$.

Fig. 10. Spoonbill Platalea leucorodia; upper wing covert $(42 \times)$.

Fig. 11. Greater Flamingo Phoenicopterus ruber; breast feather $(105 \times)$.

Fig. 12. Pochard Aythya ferina; belly feather $(105 \times)$. Heart-shaped nodes at the tips of the barbules.

The barbules of ducks show nodal arrangement for $10-35 \%$ of their length, those of geese for $30-70 \%$, and those of swans for $55-85 \%$. Only the Shelducks (genus Tadorna) form an intermediate group with $23-44 \%$. No villi at the basal cells.
8. Accipitriformes (figs. 15-16; table VII)

This order of birds of prey consists of two families (Accipitridae and Pandionidae). Seventeen species have been examined. Range of weights $103-7500 \mathrm{~g}$. 


\section{TABLE VI}

Body weight (in g) and length of barbules (in $\mathrm{mm}$ ) in Anseriformes.

\begin{tabular}{|c|c|c|c|}
\hline Species & & $\begin{array}{l}\text { body } \\
\text { weight }\end{array}$ & $\begin{array}{c}\text { barbule } \\
\text { length }\end{array}$ \\
\hline Cygnus olor & Mute Swan & $5500-15000$ & $0.8-1.1$ \\
\hline C. columbianus & Bewick's Swan & $3300-9600$ & $0.7-1.1$ \\
\hline C. cygnus & Whooper Swan & $7000-14000$ & $0.7-1.1$ \\
\hline Anser fabalis & Bean Goose & $1500-4300$ & $0.7-1.2$ \\
\hline A. brachyrhynchus & Pink-footed Goose & $1410-3350$ & $0.7-1.4$ \\
\hline A. albifrons & White-fronted Goose & $1150-3340$ & $0.6-1.4$ \\
\hline A. erythropus & Lesser White- & $1310-2500$ & $0.7-1.1$ \\
\hline A. anser & Greylag Goose & $1980-4560$ & $0.6-1.1$ \\
\hline A. indicus & Bar-headed Goose & $2000-3200$ & $0.7-1.3$ \\
\hline Branta canadensis & Canada Goose & $1100-7570$ & $0.8-1.3$ \\
\hline B. leucopsis & Barnacle Goose & $1020-2650$ & $0.9-2.0$ \\
\hline B. bernicla & Brent Goose & $850-2220$ & $0.6-1.1$ \\
\hline B. ruficollis & Red-breasted Goose & $1000-1625$ & $0.7-1.5$ \\
\hline Tadorna ferruginea & Ruddy Shelduck & $925-1600$ & $0.6-1.5$ \\
\hline T. tadorna & Shelduck & $500-1650$ & $0.6-1.3$ \\
\hline Aix galericulata & Mandarin Duck & $428-725$ & $0.8-1.7$ \\
\hline Anas penelope & Wigeon & $400-1090$ & $0.6-1.8$ \\
\hline A. strepera & Gadwall & $470-1300$ & $0.5-1.2$ \\
\hline A. crecca & Teal & $163-500$ & $0.7-1.7$ \\
\hline A. platyrhynchos & Mallard & $500-1800$ & $0.7-2.0$ \\
\hline A. acuta & Pintail & $400-1444$ & $0.7-1.1$ \\
\hline A. querquedula & Garganey & $250-600$ & $0.6-1.1$ \\
\hline A. discors & Blue-winged Teal & $188-590$ & $0.7-1.4$ \\
\hline A. clypeata & Shoveler & $300-1100$ & $0.6-1.1$ \\
\hline Netta rufina & Red-crested Pochard & $694-1550$ & $0.6-1.6$ \\
\hline Aythya ferina & Pochard & $467-1300$ & $0.7-1.2$ \\
\hline A. nyroca & Ferruginous Duck & $400-740$ & $0.6-1.1$ \\
\hline A. fuligula & Tufted Duck & $335-1400$ & $0.6-1.0$ \\
\hline A. marila & Scaup & $690-1372$ & $0.6-1.1$ \\
\hline \multicolumn{4}{|l|}{ Somateria } \\
\hline mollissima & Eider & $1150-2900$ & $0.5-0.9$ \\
\hline Clangula hyemalis & Long-tailed Duck & $453-955$ & $0.5-0.8$ \\
\hline Melanitta nigra & Common Scoter & $600-1610$ & $0.5-1.3$ \\
\hline M. fusca & Velvet Scoter & $850-2104$ & $0.5-0.8$ \\
\hline Bucephala clangula & Goldeneye & $496-1400$ & $0.7-1.2$ \\
\hline Mergus albellus & Smew & $500-950$ & $0.5-0.9$ \\
\hline \multirow[t]{2}{*}{$M$. serrator } & \multicolumn{3}{|l|}{ Red-breasted } \\
\hline & & $644-1360$ & $0.5-1.2$ \\
\hline \multirow{2}{*}{\multicolumn{4}{|c|}{$\begin{array}{l}\text { M. merganser } \\
\text { Oxyura leuco- }\end{array}$}} \\
\hline & White-headed Duck & $400-900$ & $0.7-1.1$ \\
\hline
\end{tabular}

Description. - The barbules are very long and slender (1.0-5.8 mm), and not pigmented (only in the Bateleur Terathopius ecaudatus heavily pigmented barbules are found). A subdivision of the barbules is often hardly perceptible, as the nodes are only very slightly enlarged (10-20 per $\mathrm{mm})$. They possess short prongs, which are asymmetrical in most cases. These prongs occur sometimes along the entire length of the barbule, sometimes at the tips only, but usually only at the bases. Counting the nodes or prongs is usually difficult and sometimes impossible at magnifications up to $200 \times$. No villi at the basal cells.

\section{TABLE VII}

Body weight (in $\mathrm{g}$ ) and length of barbules (in $\mathrm{mm}$ ) in Accipitriformes.

\begin{tabular}{|c|c|c|c|}
\hline Species & & $\begin{array}{c}\text { body } \\
\text { weight }\end{array}$ & $\begin{array}{c}\text { barbule } \\
\text { length }\end{array}$ \\
\hline Pernis apivorus & Honey Buzzard & $360-1490$ & $2.5-5.8$ \\
\hline Milvus migrans & Black Kite & $500-1186$ & $2.0-3.6$ \\
\hline M. milvus & Red Kite & $757-1600$ & $1.8-3.0$ \\
\hline \multicolumn{4}{|l|}{ Haliaeetus } \\
\hline albicilla & White-tailed Eagle & $3019-7500$ & $1.8-4.1$ \\
\hline \multicolumn{4}{|l|}{ Terathopius } \\
\hline ecaudatus & Bateleur & $1820-2950$ & $1.8-2.1$ \\
\hline \multicolumn{4}{|l|}{ Circus actugi- } \\
\hline nosus & Marsh Harrier & $320-1370$ & $2.3-3.7$ \\
\hline C. cyaneus & Hen Harrier & $200-740$ & $2.4-4.0$ \\
\hline C. macrourus & Pallid Harrier & $235-604$ & $2.3-3.4$ \\
\hline C. pygargus & Montagu's Harrier & $227-445$ & 2.3-3.1 \\
\hline Melierax & Dark Chanting & & \\
\hline metabates & Goshawk & $488-852$ & $1.5-2.2$ \\
\hline Accipiter gentilis & Goshawk & $517-2054$ & $1.9-4.8$ \\
\hline A. nisus & Sparrowhawk & $103-346$ & $1.8-3.8$ \\
\hline Buteo buteo & Buzzard & $427-1364$ & $1.8-4.1$ \\
\hline \multirow[t]{2}{*}{ B. lagopus } & Rough-legged & & \\
\hline & Buzzard & $600-1660$ & $1.9-3.4$ \\
\hline Aquila rapax & Steppe Eagle & $1572-4850$ & $2.4-3.8$ \\
\hline A. chrysaetos & Golden Eagle & $2840-6665$ & $2.0-3.5$ \\
\hline \multicolumn{4}{|l|}{ Pandion } \\
\hline haliaetus & Osprey & $1120-2050$ & $1.0-1.7$ \\
\hline
\end{tabular}

\section{Falconiformes (figs. 17-18; table VIII)}

Nine species of the family Falconidae have been examined. Range of weights $90-2100 \mathrm{~g}$.

Description. - The barbules are rather long (1.1-3.4 $\mathrm{mm}$ ) and always clearly divided along their entire length into slightly enlarged and heavily pigmented nodes, and very slender and wavy internodes. In this they are completely different from the Accipitriformes. The number of nodes can always be counted and varies from 11 to 24. Larger birds tend to possess longer barbules with fewer nodes per mm than smaller birds, but the differences are too small to be diagnostic. No prongs are found in this group 

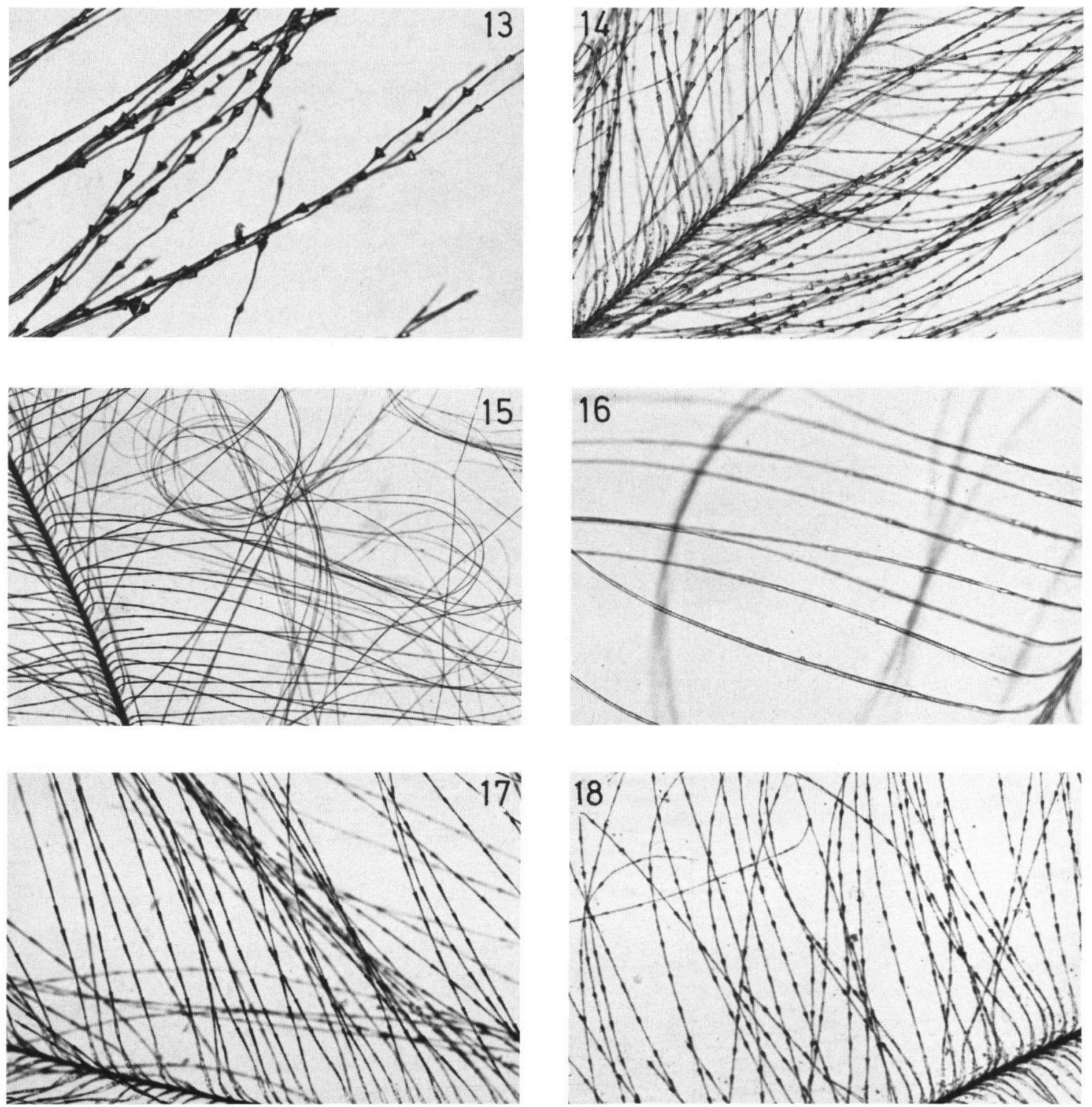

Fig. 13. Barnacle Goose Branta leucopsis; back feather $(105 \times)$. Barbules show characteristic kinking.

Fig. 14. Whooper Swan Cygnus cygnus; neck feather $(105 \times)$.

Fig. 15. Goshawk Accipiter gentilis; upper wing covert $(42 \times)$.

Fig. 16. Buzzard Buteo buteo; breast feather $(130 \times)$.

Fig. 17. Hobby Falco subbuteo; breast feather $(85 \times)$.

Fig. 18. Red-footed Falcon Falco vespertinus; breast feather $(85 \times)$.

(at magnifications up to $200 \times$ ). No villi at the basal cells.

\section{Galliformes (figs. 19-20; table IX)}

Thirteen species from two families (Tetraonidae and Phasianidae) have been examined. Range of weights 52-6500 g.
Description. - The barbules are very long $(1.6-5.5 \mathrm{~mm})$ and they are always clearly divided along their entire length into pigmented nodes and filamentous internodes. At their proximal part the barbules possess poorly developed nodes, which, however, soon increase in width and develop a typical ring-like shape. Frequently, some of these rings become 


\section{TABLE VIII}

Body weight (in $\mathrm{g}$ ), length of barbules (in $\mathrm{mm}$ ), and number of nodes (per mm barbule) in Falconiformes.

\begin{tabular}{llrrr}
\hline Species & & $\begin{array}{c}\text { body } \\
\text { weight }\end{array}$ & $\begin{array}{c}\text { barbule } \\
\text { length }\end{array}$ & $\begin{array}{c}N \text { of } \\
\text { nodes }\end{array}$ \\
\hline Falco naumanni & Lesser Kestrel & $90-208$ & $1.2-2.1$ & $13-22$ \\
$F$. tinnunculus & Kestrel & $113-314$ & $1.2-2.6$ & $13-24$ \\
$F$. sparverius & American Kestrel & $95-130$ & $1.1-2.5$ & $13-23$ \\
F. vespertinus & $\begin{array}{c}\text { Red-footed } \\
\text { Falcon }\end{array}$ & $130-197$ & $1.4-2.4$ & $13-23$ \\
F. columbarius & Merlin & $125-300$ & $1.4-2.6$ & $14-23$ \\
F. subbuteo & Hobby & $131-340$ & $1.3-2.7$ & $14-21$ \\
F. eleonorae & Eleonora's & & & \\
& $\quad$ Falcon & $270-510$ & $1.4-2.6$ & $13-18$ \\
F. rusticolus & Gyr Falcon & $800-2100$ & $1.5-3.4$ & $11-17$ \\
F. peregrinus & Peregrine & $330-1333$ & $1.8-3.0$ & $12-19$ \\
\hline
\end{tabular}

detached and slide along the slender internodes like rings on a wire, breaking up into groups of 2-10 (multiple nodes; fig. 20). Toward the tips of the barbules, the ring-like structure is again lost, and the nodes become simply swollen. Larger birds tend to have longer barbules and fewer nodes per mm. Multiple nodes are not always present in great numbers and may be difficult to find. No villi at the basal cells.

\section{TABLE IX}

Body weight (in $\mathrm{g}$ ), length of barbules (in $\mathrm{mm}$ ), and number of nodes (per mm barbule) in Galliformes (multiple nodes not included).

\begin{tabular}{|c|c|c|c|c|}
\hline \multicolumn{2}{|l|}{ Species } & \multirow{2}{*}{$\begin{array}{c}\begin{array}{c}\text { body } \\
\text { weight }\end{array} \\
278-500\end{array}$} & \multirow{2}{*}{$\begin{array}{c}\text { barbule } \\
\text { length }\end{array}$} & \multirow{2}{*}{$\begin{array}{c}\begin{array}{c}N \text { of } \\
\text { nodes }\end{array} \\
20-28\end{array}$} \\
\hline Bonasa bonasia & Hazel Grouse & & & \\
\hline \multirow[t]{2}{*}{ Lagopus lagopus } & Willow/Red & & & \\
\hline & Grouse & $400-908$ & $1.7-3.3$ & $20-29$ \\
\hline L. mutus & Ptarmigan & $243-610$ & $2.0-3.9$ & $14-26$ \\
\hline Tetrao tetrix & Black Grouse & $615-1750$ & $2.8-3.8$ & $13-24$ \\
\hline T. urogallus & Capercaillie & $1370-6500$ & $2.2-5.5$ & $15-26$ \\
\hline Callipepla & California & & & \\
\hline californica & Quail & $130-207$ & $1.7-3.0$ & $20-34$ \\
\hline Alectoris chukar & Chukar & $365-595$ & $2.3-3.6$ & $18-27$ \\
\hline \multirow[t]{2}{*}{ A. rufa } & Red-legged & & & \\
\hline & Partridge & $240-547$ & $1.9-3.0$ & $23-31$ \\
\hline \multicolumn{5}{|l|}{ Francolinus } \\
\hline francolinus & Black Francolin & $227-570$ & $2.5-3.3$ & $22-28$ \\
\hline Perdix perdix & Partridge & $310-480$ & $2.1-4.0$ & $22-30$ \\
\hline Coturnix coturmix & Quail & $52-155$ & $1.8-2.6$ & $25-35$ \\
\hline C. japonica & Japanese Quail & - & $1.6-2.4$ & $25-35$ \\
\hline \multicolumn{5}{|l|}{ Phasianus } \\
\hline colchicus & Pheasant & $500-2015$ & $2.5-4.1$ & $15-23$ \\
\hline
\end{tabular}

\section{Gruiformes (figs. 21-23; table X)}

Fifteen species from five families (Turnicidae, Rallidae, Aramidae, Gruidae, and Otididae) have been examined. Range of weights 28$18000 \mathrm{~g}$.

Description. - The barbules vary from extremely short $(0.4 \mathrm{~mm})$ to extremely long $(5.9 \mathrm{~mm})$. Large differences exist between the families that were studied. In none of them villi are present at the basal cells.

Turnicidae: The barbules are short (0.6-1.3 $\mathrm{mm}$ ) and subdivided along their entire length by pigmented, but hardly enlarged nodes (2329 per $\mathrm{mm}$, difficult to count).

Rallidae: The barbules are rather short (0.4$1.7 \mathrm{~mm}$ ) and subdivided into heavily pigmented nodes (15-32 per $\mathrm{mm}$ ) and short internodes. The pigment is mainly present in the nodes and the distal part of the internodes. The minute prongs at the nodes and the proximal part of the internodes are more or less unpigmented. Towards the base of the barbules usually 2-4 nodes are enlarged, whereas further along the barbule and in the tip region they are only slightly swollen and often difficult to

\section{TABle $X$}

Body weight (in $\mathrm{g}$ ), length of barbules (in $\mathrm{mm}$ ), and number of nodes (per $\mathrm{mm}$ barbule) in Gruiformes.

\begin{tabular}{|c|c|c|c|c|}
\hline Species & & $\begin{array}{l}\text { body } \\
\text { weight }\end{array}$ & $\begin{array}{l}\text { barbule } \\
\text { length }\end{array}$ & $\begin{array}{l}N \text { of } \\
\text { nodes }\end{array}$ \\
\hline \multirow[t]{2}{*}{ Turnix sylvatica } & Andalusian & & & \\
\hline & Hemipode & $29-70$ & $0.6-1.3$ & $23-29$ \\
\hline Rallus aquaticus & Water Rail & $74-190$ & $0.6-1.1$ & $26-32$ \\
\hline Porzana porzana & Spotted Crake & $47-147$ & $0.5-1.3$ & $22-28$ \\
\hline P. parva & Little Crake & $30-72$ & $0.5-1.2$ & $25-30$ \\
\hline P. pusilla & Baillon's Crake & $28-60$ & $0.5-1.2$ & $26-30$ \\
\hline Crex crex & Corn Crake & $95-210$ & $0.5-1.4$ & $22-29$ \\
\hline \multicolumn{5}{|l|}{ Gallinula } \\
\hline chloropus & Moorhen & $140-493$ & $0.7-1.5$ & $19-29$ \\
\hline \multicolumn{5}{|l|}{ Porphyrio } \\
\hline porphyrio & Purple Coot & $325-1000$ & $0.6-1.7$ & $15-19$ \\
\hline Gallicrex cinerea & Watercock & $200-510$ & $0.4-1.3$ & $21-26$ \\
\hline Fulica atra & Coot & $300-1460$ & $0.6-1.4$ & $18-24$ \\
\hline Grus grus & Common Crane & $3000-7000$ & $1.0-2.2$ & 一 \\
\hline Anthropoides & Demoiselle & & & \\
\hline virgo & Crane & $1985-3060$ & $0.8-2.2$ & 一 \\
\hline Tetrax tetrax & Little Bustard & $525-1000$ & $1.7-3.8$ & - \\
\hline \multicolumn{5}{|l|}{ Chlamydotis } \\
\hline undulata & Houbara & $1100-1375$ & $1.9-4.9$ & - \\
\hline Otis tarda & Great Bustard & $3200-18000$ & $2.0-5.9$ & - \\
\hline
\end{tabular}



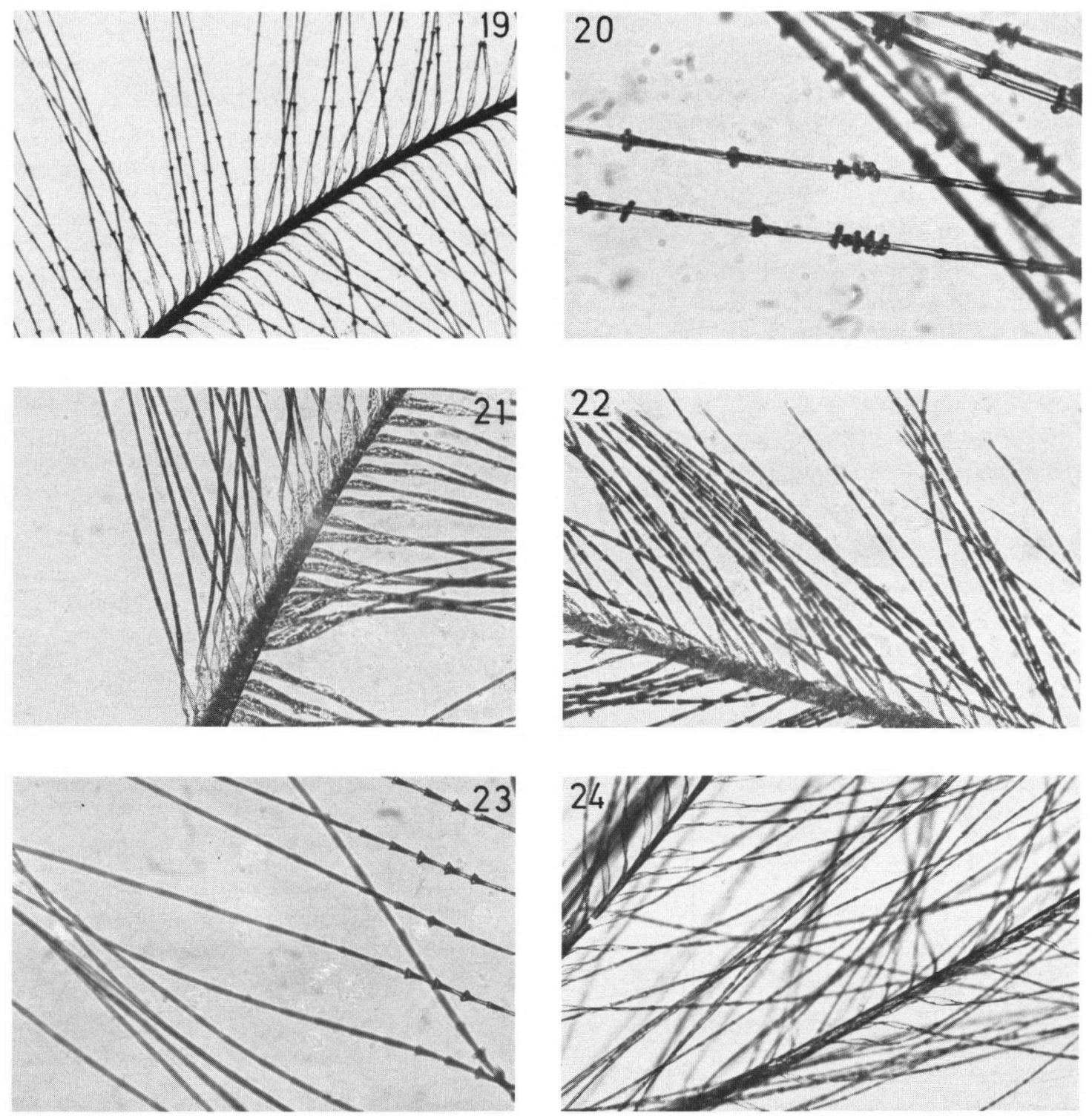

Fig. 19. Black Grouse Tetrao tetrix; breast feather $(85 \times)$.

Fig. 20. Black Grouse Tetrao tetrix; breast feather $(325 \times)$. Barbules with multiple nodes

Fig. 21. Andalusian Hemipode Turnix sylvatica; breast feather $(105 \times)$.

Fig. 22. Spotted Crake Porzana porzana; under tail covert $(105 \times)$.

Fig. 23. Watercock Gallicrex cinerea; breast feather $(105 \times)$.

Fig. 24. Oystercatcher Haematopus ostralegus; thigh feather $(130 \times)$.

count. This reduction in the size of the nodes takes place quite abruptly over a distance of $1-3$ internodes and is always more pronounced in one of both vanules. Larger birds tend to have fewer nodes per $\mathrm{mm}$ than smaller birds.

Gruidae: The barbules are of medium length $(0.8-2.2 \mathrm{~mm})$, not pigmented, and have the form of almost unmodified threads, which, however, at higher magnification $(200 \times)$ show minute prongs at the nodes; two of a pair of prongs are usually of unequal size. The small nodes and prongs cannot be counted.

Otididae: The barbules are extremely long (1.7-5.9 mm), not pigmented, and only 
inconspicuously subdivided by nodes (but not by prongs). Only towards the bases some very slightly enlarged (but unpigmented) nodes are visible, which are too few in number to be counted.

\section{Charadrilformes (figs. 24-33; table XI)}

Sixty-eight species from nine families (Haematopodidae, Recurvirostridae, Glareolidae, Charadriidae, Scolopacidae, Stercorariidae, Laridae, Sternidae, and Alcidae) have been examined. Range of weights 14-2700 g.

Description. - The length of the barbules varies between 0.4 and $3.4 \mathrm{~mm}$. Large differences exist between the nine families in the length of the barbules, degree of pigmentation, presence of prongs, and number of nodal structures per mm. No villi are present at the basal cells.

Haematopodidae: The barbules vary from 0.7 to $1.7 \mathrm{~mm}$ and are subdivided by nodes (1723 per $\mathrm{mm}$ ) which are not pigmented (thus, completely different from Lapwing). Towards the tips of the barbules, the nodes gradually become smaller and less conspicuous, and distally they often show short prongs.

Recurvirostridae: The barbules vary from 0.6 to $1.5 \mathrm{~mm}$ and are always subdivided by usually unpigmented nodes (but sometimes pigmented and situated at the bases of the barbules) which may possess minute prongs.

Glareolidae: The barbules vary from 0.5 to $1.3 \mathrm{~mm}$ and they are always subdivided by pigmented nodes (19-27 per $\mathrm{mm}$ ).

\section{TABLE XI}

Body weight (in $\mathrm{g}$ ), length of barbules (in $\mathrm{mm}$ ), and number of nodal structures (per $\mathrm{mm}$ barbule) in Charadriiformes.

\begin{tabular}{llccc}
\hline Species & & $\begin{array}{c}\text { body } \\
\text { weight }\end{array}$ & $\begin{array}{c}\text { barbule } \\
\text { length }\end{array}$ & $\begin{array}{c}N \text { of } \\
\text { nodes }\end{array}$ \\
\hline $\begin{array}{l}\text { Hacmatopus ostralegus } \\
\text { Himantopus }\end{array}$ & Oystercatcher & $284-745$ & $0.7-1.7$ & $17-23$ \\
$\quad$ himantopus & Black-winged Stilt & $132-289$ & $0.6-1.5$ & $17-26$ \\
$\begin{array}{l}\text { Recurvirostra avosetta } \\
\text { Glareola pratincola }\end{array}$ & $\begin{array}{l}\text { Avocet } \\
\text { Pratincole }\end{array}$ & $231-435$ & $0.6-1.4$ & $17-24$ \\
G. nordmanni & Black-winged & $60-95$ & $0.5-1.3$ & $19-27$ \\
& $\quad$ Pratincole & $87-105$ & $0.6-1.2$ & $20-27$ \\
Charadrius dubius & Little Ringed Plover & $26-54$ & $0.5-1.2$ & $23-29$
\end{tabular}

TABLE XI (continuation)

\begin{tabular}{|c|c|c|c|c|}
\hline Species & & $\begin{array}{l}\text { body } \\
\text { weight }\end{array}$ & $\begin{array}{l}\text { barbule } \\
\text { length }\end{array}$ & $\begin{array}{l}N \text { of } \\
\text { nodes }\end{array}$ \\
\hline C. hiaticula & Ringed Plover & $27-81$ & $0.6-1.5$ & $20-26$ \\
\hline C. vociferus & Killdeer & $65-90$ & $0.9-1.5$ & $22-27$ \\
\hline C. alexandrinus & Kentish Plover & $32-69$ & $0.5-1.3$ & $23-32$ \\
\hline C. mongolus & Lesser Sand Plover & $39-126$ & $0.8-1.3$ & $22-27$ \\
\hline C. leschenaultii & Greater Sand Plover & $60-120$ & $0.7-1.3$ & $21-29$ \\
\hline C. asiaticus & Caspian Plover & $60-91$ & $0.7-1.3$ & $22-34$ \\
\hline Eudromias morinellus & Dotterel & $86-142$ & $0.8-2.2$ & $19-30$ \\
\hline Pluvialis apricaria & Golden Plover & $88-239$ & $0.6-1.7$ & $19-26$ \\
\hline$P$. squatarola & Grey Plover & $105-335$ & $0.6-1.9$ & $18-24$ \\
\hline Hoplopterus spinosus & $\begin{array}{l}\text { Spur-winged } \\
\text { Lapwing }\end{array}$ & $127-170$ & $0.9-1.3$ & $18-22$ \\
\hline Chettusia gregaria & Sociable Lapwing & $180-260$ & $0.7-1.7$ & $16-21$ \\
\hline C. leucura & $\begin{array}{l}\text { White-tailed } \\
\text { Lapwing }\end{array}$ & $99-198$ & $0.7-1.4$ & $22-27$ \\
\hline Vanellus vanellus & Lapwing & $112-330$ & $0.4-1.5$ & $24-35$ \\
\hline Calidris canutus & Knot & $82-230$ & $0.5-1.4$ & $26-35$ \\
\hline C. alba & Sanderling & $41-88$ & $0.5-1.2$ & $25-32$ \\
\hline C. minula & Little Stint & $14-44$ & $0.5-1.2$ & 24-34 \\
\hline C. temminckii & Temminck's Stint & $15-35$ & $0.6-1.6$ & $23-33$ \\
\hline C. ferruginea & Curlew Sandpiper & $32-100$ & $0.5-1.2$ & $26-35$ \\
\hline C. alpina & Dunlin & $26-74$ & $0.5-1.4$ & $29-39$ \\
\hline Philomachus pugnax & Ruff & $67-254$ & $0.5-1.4$ & $25-33$ \\
\hline Lymnocryptes minimus & Jack Snipe & $43-92$ & $0.5-1.3$ & $30-37$ \\
\hline Gallinago gallinago & Common Snipe & $76-227$ & $0.5-1.4$ & $24-33$ \\
\hline G. media & Great Snipe & $140-265$ & $0.6-1.5$ & $19-30$ \\
\hline Scolopax rusticola & Woodcock & $198-520$ & $1.1-3.4$ & $14-18$ \\
\hline Limosa limosa & Black-tailed Godwit & $160-500$ & $0.5-1.3$ & $26-35$ \\
\hline L. lapponica & Bar-tailed Godwit & $147-373$ & $0.5-1.6$ & $23-29$ \\
\hline Numenius phacopus & Whimbrel & $227-660$ & $0.5-1.0$ & $27-34$ \\
\hline$N$. arquata & Curlew & $410-1280$ & $0.5-1.1$ & $25-31$ \\
\hline Tringa erythropus & Spotted Redshank & $97-205$ & $0.5-1.2$ & $25-31$ \\
\hline$T$. totanus & Redshank & $78-166$ & $0.6-1.4$ & $25-33$ \\
\hline$T$. stagnatilis & Marsh Sandpiper & $36-120$ & $0.5 \cdot 1.5$ & $26-34$ \\
\hline$T$. nebularia & Greenshank & $134-283$ & $0.5-1.3$ & $22-28$ \\
\hline T. ochropus & Green Sandpiper & $50-112$ & $0.6-1.4$ & $25-31$ \\
\hline T. glareola & Wood Sandpiper & $34-89$ & $0.6-1.2$ & $26-35$ \\
\hline Actitis hypoleucos & Common Sandpiper & $28-73$ & $0.6-1.6$ & $24-30$ \\
\hline Arenaria interpres & Turnstone & $73-195$ & $0.5-1.2$ & $26-32$ \\
\hline \multirow[t]{2}{*}{ Phalaropus lobatus } & Red-necked & & & \\
\hline & Phalarope & $25-48$ & $0.5-1.1$ & $25-34$ \\
\hline P. fulicarius & Grey Phalarope & $30-77$ & $0.5-1.1$ & $25-33$ \\
\hline Siercorarius pomarinus & Pomarine Skua & $469-917$ & $0.6-1.1$ & $18-27$ \\
\hline S. parasiticus & Arctic Skua & $297-644$ & $0.6-1.1$ & $18-27$ \\
\hline S. longicaudus & Long-tailed Skua & $195-444$ & $0.6-1.2$ & $20-27$ \\
\hline S. skua & Great Skua & $600-2040$ & $0.5-1.0$ & $20-26$ \\
\hline Larus minutus & Little Gull & $80-150$ & $0.5-1.0$ & $19-24$ \\
\hline L. ridibundus & Black-headed Gull & $116-390$ & $0.5-1.3$ & $16-22$ \\
\hline L. canus & Common Gull & $300-586$ & $0.5-1.3$ & $16-22$ \\
\hline \multirow[t]{2}{*}{ L. fuscus } & Lesser Black- & & & \\
\hline & backed Gull & $534-1180$ & $0.6-1.2$ & $17-22$ \\
\hline L. argentatus & Herring Gull & $600-1800$ & $0.7-1.2$ & $16-21$ \\
\hline L. hyperboreus & Glaucous Gull & $1151-2700$ & $0.5-1.2$ & $18-22$ \\
\hline L. marinus & $\begin{array}{l}\text { Great Black- } \\
\text { backed Gull }\end{array}$ & $996-2275$ & $0.7-1.4$ & $15-20$ \\
\hline Rissa tridactyla & Kittiwake & $210-610$ & $0.5-1.2$ & $18-23$ \\
\hline Gelochelidon nilotica & Gull-billed Tern & $154-290$ & $0.6-1.1$ & $19-25$ \\
\hline Sterna sandvicensis & Sandwich Tern & $174-330$ & $0.6-1.1$ & $20-25$ \\
\hline S. hirundo & Common Tern & $76-175$ & $0.6-1.1$ & $18-26$ \\
\hline S. paradisaea & Arctic Tern & $87-142$ & $0.6-1.1$ & $19-24$ \\
\hline S. albifrons & Little Tern & $31-60$ & $0.5-1.0$ & $22-29$ \\
\hline Chlidonias hybrida & Whiskered Tern & $61-94$ & $0.6-1.2$ & $19-24$ \\
\hline C. nigra & Black Tern & $51-77$ & $0.7-1.2$ & $20-24$ \\
\hline Uria aalge & Guillemot & $612-1200$ & $0.4-0.8$ & - \\
\hline \multirow[t]{2}{*}{ U. lomvia } & Brünnich's & & & \\
\hline & Guillemot & $604-1200$ & $0.4-0.9$ & - \\
\hline Alca torda & Razorbill & $450-920$ & $0.4-0.9$ & - \\
\hline Cepphus grylle & Black Guillemot & $312-615$ & $0.6-1.1$ & - \\
\hline Fratercula arctica & Puffin & $290-586$ & $0.4-1.0$ & - \\
\hline
\end{tabular}





Fig. 25. Avocet Recurvirostra avosetta; breast feather $(85 \times)$.

Fig. 26. Pratincole Glareola pratincola; belly feather $(205 \times)$.

Fig. 27. Golden Plover Pluvialis apricaria; breast feather $(85 \times)$.

Fig. 28. Ringed Plover Charadrius hiaticula; belly feather $(205 \times)$.

Fig. 29. Dunlin Calidris alpina; breast feather $(85 \times)$.

Fig. 30. Long-tailed Skua Stercorarius longicaudus; mantle feather $(85 \times)$.

Charadriidae: The barbules vary from 0.4 to $2.2 \mathrm{~mm}$ and they are always clearly subdivided by nodes (16-35 per $\mathrm{mm}$ ), which may be pigmented as well as unpigmented. Prongs are not found within this family (at magnifications between 50 and $500 \times$ ). Pigmented nodes are always found at the basal portion of the most basal barbules. Considerable differences in the extent of pigmentation exist. In the Golden Plover Pluvialis apricaria some unpigmented nodes are found at the tips of the barbules only while the remaining nodes are all pigmented. In Charadrius usually only the nodes at the basal part of the most basal barbules are pigmented. 
Scolopacidae: The barbules are rather short (0.5-1.6 mm; only in Scolopax they reach up to $3.4 \mathrm{~mm}$ ). In some genera, such as Scolopax, Gallinago, Lymnocryptes, and Phalaropus the barbules are conspicuously subdivided by nodes (14-37 per $\mathrm{mm}$ ) which are always pigmented. In the remaining species, pigmented as well as unpigmented nodes occur (22-39 per $\mathrm{mm}$ ), which occasionally possess minute prongs. In Numenius the nodes are usually not pigmented, but pigmented ones may occur. In Calidris, Tringa, Limosa, Arenaria, and Philomachus the nodes are usually pigmented, but especially towards the tips of the barbules unpigmented nodes occur as well.

Stercorariidae: The barbules are very short (0.5-1.2 $\mathrm{mm})$ and they are subdivided by unpigmented nodes or minute prongs (18-27 per $\mathrm{mm}$ ).

Laridae: The barbules are short and along most of their length subdivided by unpigmented and rather inconspicuous nodes which often possess prongs. Always only the most basal barbules possess 3-8 enlarged and heavily pigmented nodes proximally.

Sternidae: This group closely resembles the gulls. The barbules vary from 0.5 to $1.2 \mathrm{~mm}$ and there are 18-29 nodal structures per $\mathrm{mm}$.

Alcidae: The barbules are extremely short (0.4-1.1 $\mathrm{mm})$ and they are faintly subdivided by indistinct nodes or well-developed prongs, which are most prominent distally. Often an inconspicuous and diffuse pigmentation is present.

\section{Pteroclidiformes (fig. 34 ; table XII)}

This order consists of a single family (Pteroclididae). Three species have been examined. Range of weights 200-650 g.

Description. - The barbules are very long (1.6-4.8 $\mathrm{mm})$ and along their entire length divided into nodes (11-17 per $\mathrm{mm}$ ) which often possess minute prongs, and internodes, both unpigmented. Onily proximally 3-5 nodes are slightly enlarged and rather conspicuous, further along the barbules they are often hard to count. No villi at the basal cells.
TABle XII

Body weight (in $\mathrm{g}$ ), length of barbules (in $\mathrm{mm}$ ), and number of nodal structures (per $\mathrm{mm}$ barbule) in Pteroclidiformes.

\begin{tabular}{llccc}
\hline Species & body & $\begin{array}{c}\text { barbule } \\
\text { weight }\end{array}$ & $\begin{array}{c}N \text { of } \\
\text { nodes }\end{array}$ \\
\hline Plerocles alchata & $\begin{array}{c}\text { Pin-tailed Sand- } \\
\text { grouse }\end{array}$ & $200-340$ & $1.6-3.0$ & $12-17$ \\
B. orientalis & $\begin{array}{c}\text { Black-bellied Sand- } \\
\text { grouse }\end{array}$ & $410-650$ & $1.6-4.8$ & $12-17$ \\
Syrrhaptes paradoxus & Pallas's Sandgrouse & $254-340$ & $1.7-4.2$ & $11-15$ \\
\hline
\end{tabular}

\section{Columbiformes (fig. 35; table XIII)}

This order consists of a single family (Columbidae). Five species have been examined. Range of weights 74-739 g.

Description. - The barbules are very long (1.1-5.1 mm); on the basal part a number of very large, flattened, plate-like nodes are found: usually 3-8 of full size, then a number of smaller and less conspicuous ones, decreasing in size until they almost completely disappear, the whole distal portion of the barbule being smoothly filamentous or with very minute swollen nodes (occasionally with minute prongs). Only the most basal barbules of the feather possess expanded, quadrilobed nodes along their whole length (10-18 per $\mathrm{mm}$ ). Pigmentation is slight and confined to the nodes. Among the species examined no diagnostic differences are found in the length of the barbules or the number of nodes per $\mathrm{mm}$. No villi at the basal cells.

\section{TABLE XIII}

Body weight (in $\mathrm{g}$ ), length of barbules (in $\mathrm{mm}$ ), and number of nodes (per $\mathrm{mm}$ barbule) in Columbiformes.

\begin{tabular}{llrcc}
\hline Species & & $\begin{array}{c}\text { body } \\
\text { weight }\end{array}$ & $\begin{array}{c}\text { barbule } \\
\text { length }\end{array}$ & $\begin{array}{c}N \text { of } \\
\text { nodes }\end{array}$ \\
\hline Columba livia & $\begin{array}{c}\text { Rock Dove/ } \\
\text { Feral Dove }\end{array}$ & $194-570$ & $1.2-4.4$ & $11-16$ \\
& Stock Dove & $217-567$ & $1.1-4.7$ & $10-16$ \\
$\begin{array}{l}\text { C. oenas } \\
\text { C. palumbus }\end{array}$ & Wood Pigeon & $258-739$ & $1.2-4.6$ & $10-16$ \\
$\begin{array}{l}\text { Streptopelia } \\
\text { decaocto }\end{array}$ & Collared Dove & $113-243$ & $1.2-4.8$ & $12-18$ \\
$S$. turtur & Turtle Dove & $74-178$ & $1.3-5.1$ & $11-17$ \\
\hline
\end{tabular}



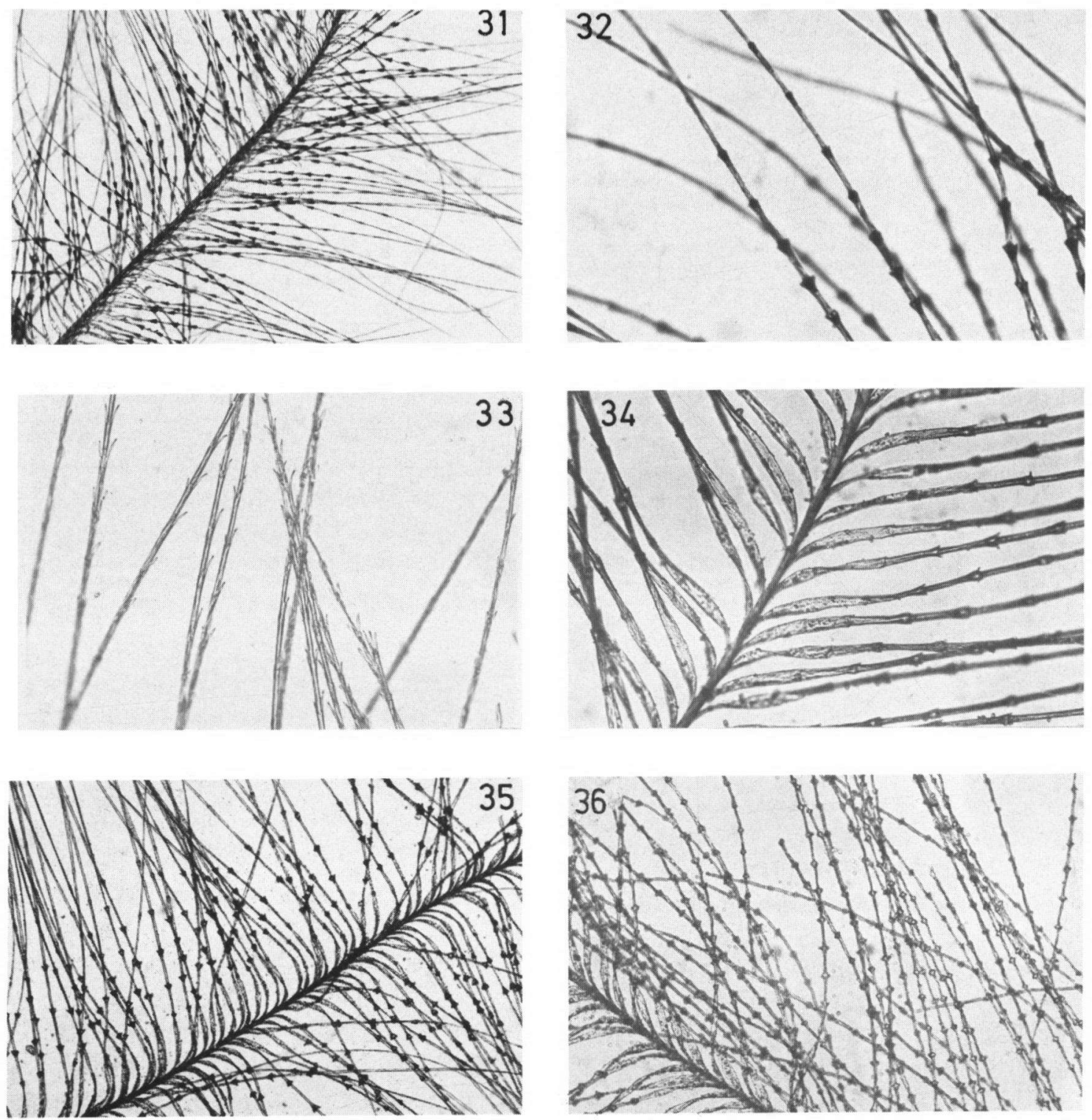

Fig. 31. Little Gull Larus minutus; breast feather $(85 \times)$. Fig. 32. Kittiwake Rissa tridactyla; belly feather $(205 \times)$.

Fig. 33. Razorbill Alca lorda; breast feather $(205 \times)$.

Fig. 34. Pallas's Sandgrouse Syrthaptes paradoxus; belly feather $(205 \times)$

Fig. 35. Wood Pigeon Columba palumbus; mantle feather $(85 \times)$.

Fig. 36. Budgerigar Melopsittacus undulatus; belly feather $(105 \times)$.

\section{Psittaciformes (fig. 36 ; table XIV)}

Ten species from three families (Loriidae, Cacatuidae, and Psittacidae) have been examined. Range of weights 33-1286 g.

Description. - The barbules are long (0.8$3.5 \mathrm{~mm}$ ) and possess globular or triangular nodes (12-34 per $\mathrm{mm}$ ) which are enlarged proximally but minute distally. Larger birds tend to possess fewer nodes per mm than smaller birds. Deeply pigmented nodes as well as unpigmented nodes can be found; in the first case the barbules may resemble those of the Passeriformes, but they are more slender and 
wavy. The internodes sometimes show a bending or kinking. No villi at the basal cells.

\section{TABLE XIV}

Body weight (in $\mathrm{g}$ ), length of barbules (in $\mathrm{mm}$ ), and number of nodes (per $\mathrm{mm}$ barbule) in Psittaciformes.

\begin{tabular}{|c|c|c|c|c|}
\hline Species & & $\begin{array}{l}\text { body } \\
\text { weight }\end{array}$ & $\begin{array}{l}\text { barbule } \\
\text { length }\end{array}$ & $\begin{array}{l}N \text { of } \\
\text { nodes }\end{array}$ \\
\hline \multicolumn{5}{|l|}{ Melopsittacus } \\
\hline undulatus & Budgerigar & ca. 33 & $0.8-1.6$ & 23-34 \\
\hline Nymphicus hollandicus & Cockatiel & $72-113$ & $1.4-2.8$ & $13-21$ \\
\hline \multirow[t]{2}{*}{ Cacatua sulphurea } & Sulphur-crested & & & \\
\hline & Cockatoo & $320-358$ & $1.4-3.5$ & $14-23$ \\
\hline Psittacus erithacus & Grey Parrot & $200-300$ & $1.3-2.6$ & $17-25$ \\
\hline Lorius domicellus & Purple-naped Lory & - & $1.5-2.3$ & $16-24$ \\
\hline \multirow[t]{2}{*}{ Agapornis taranta } & Black-winged & & & \\
\hline & Lovebird & ca. 38 & $1.1-1.8$ & 24-33 \\
\hline \multirow[t]{2}{*}{ Loriculus stigmatus } & Celebes Hanging & & & \\
\hline & Parrot & $37-49$ & $1.4-2.0$ & $20-30$ \\
\hline Poicephalus rueppellii & Rüppell's Parrot & - & $1.5-2.3$ & $17-28$ \\
\hline \multirow{3}{*}{$\begin{array}{l}P \text {. senegalus } \\
\text { Ara ararauna }\end{array}$} & Senegal Parrot & - & $1.2-2.5$ & $19-27$ \\
\hline & Blue and Yellow & & & \\
\hline & Macaw & $1157-1286$ & $1.5-2.9$ & $12-22$ \\
\hline
\end{tabular}

16. Cuguliformes (fig. 37)

Two species of the family Cuculidae have been examined. Range of weights $63-220 \mathrm{~g}$.

Description. - The barbules are very long (1.4-3.2 $\mathrm{mm}$ in Great Spotted Cuckoo Clamator glandarius and $1.5-5.0 \mathrm{~mm}$ in Cuckoo Cuculus canorus) and very slender. They have globular nodes (8-18 per $\mathrm{mm})$; those towards the base are large, whereas more distally they are minute. The internodes are extremely long and slender, and they sometimes show a slight kinking. No villi at the basal cells.

\section{Strigiformes (figs. $38-39$; table XV)}

This order consists of two families (Tytonidae and Strigidae) from which ten species have been examined. Range of weights 50-3260 g.

Description. - The barbules are very long (1.0-6.1 $\mathrm{mm})$ and are divided by pigmented nodes along their entire length (8-30 per $\mathrm{mm}$ ). The nodes show an abrupt reduction in size: 26 proximal nodes are enlarged, the remaining ones are small and longitudinally shaped. The degree of pigmentation varies from species to species. The Snowy Owl Nyctea scandiaca shows little pigmentation, whereas in the Tawny Owl
Strix aluco pigmentation is quite heavy. No villi at the basal cells.

\section{TABLE XV}

Body weight (in g), length of barbules (in $\mathrm{mm}$ ), and number of nodes (per $\mathrm{mm}$ barbule) in Strigiformes.

\begin{tabular}{llccr}
\hline Species & & $\begin{array}{c}\text { body } \\
\text { weight }\end{array}$ & $\begin{array}{c}\text { barbule } \\
\text { length }\end{array}$ & $\begin{array}{c}N \text { of } \\
\text { nodes }\end{array}$ \\
\hline Tyto alba & Barn Owl & $206-660$ & $1.5-3.7$ & $8-15$ \\
Otus scops & Scops Owl & $50-145$ & $1.6-3.1$ & $13-23$ \\
Bubo bubo & Eagle Owl & $2000-3260$ & $1.6-6.1$ & $10-19$ \\
$\begin{array}{l}\text { Nyctea scandiaca } \\
\text { Glaudicium }\end{array}$ & Snowy Owl & $710-2950$ & $2.0-4.3$ & $10-15$ \\
$\quad$ passerinum & Pygmy Owl & $55-79$ & $1.0-2.4$ & $15-26$ \\
Athene noctua & Little Owl & $85-271$ & $1.2-2.9$ & $15-24$ \\
Strix aluco & Tawny Owl & $264-695$ & $1.5-4.1$ & $12-21$ \\
Asio otus & Long-eared & & & \\
& Owl & $151-378$ & $1.7-5.2$ & $10-17$ \\
A. flammeus & Short-eared & & & \\
Aegolius & Owl & $229-500$ & $2.0-4.2$ & $10-17$ \\
funereus & Tengmalm's & & & \\
\hline
\end{tabular}

18. Caprimulgiformes (fig. 40)

Three species of the family Caprimulgidae have been examined: Nightjar Caprimulgus europaeus, Red-necked Nightjar C. ruficollis, and Egyptian Nightjar C. aegyptius. Range of weights 45-100 g.

Description. - The barbules are of medium length $(1.3-3.0 \mathrm{~mm})$ and at low magnifications $(50 \times)$ they appear as dark and heavily pigmented threads, resembling those of Apodiformes. At higher magnification $(200 \times)$, the subdivision into nodes and internodes becomes perceptible, but even then only $2-5$ basal nodes are visible. Thus, the number of nodes can only be estimated (14-16 per mm). No villi at the basal cells.

\section{Apodiformes (fig. 41)}

Two species of the family Apodidae have been examined: Swift Apus apus and Alpine Swift $A$. melba. Range of weights 22-120 g.

Description. - The barbules are rather short (0.7-1.7 mm). At low magnification $(50 \times)$ they appear as dark, heavily pigmented threads; at higher magnification $(200 \times)$, a sub- 

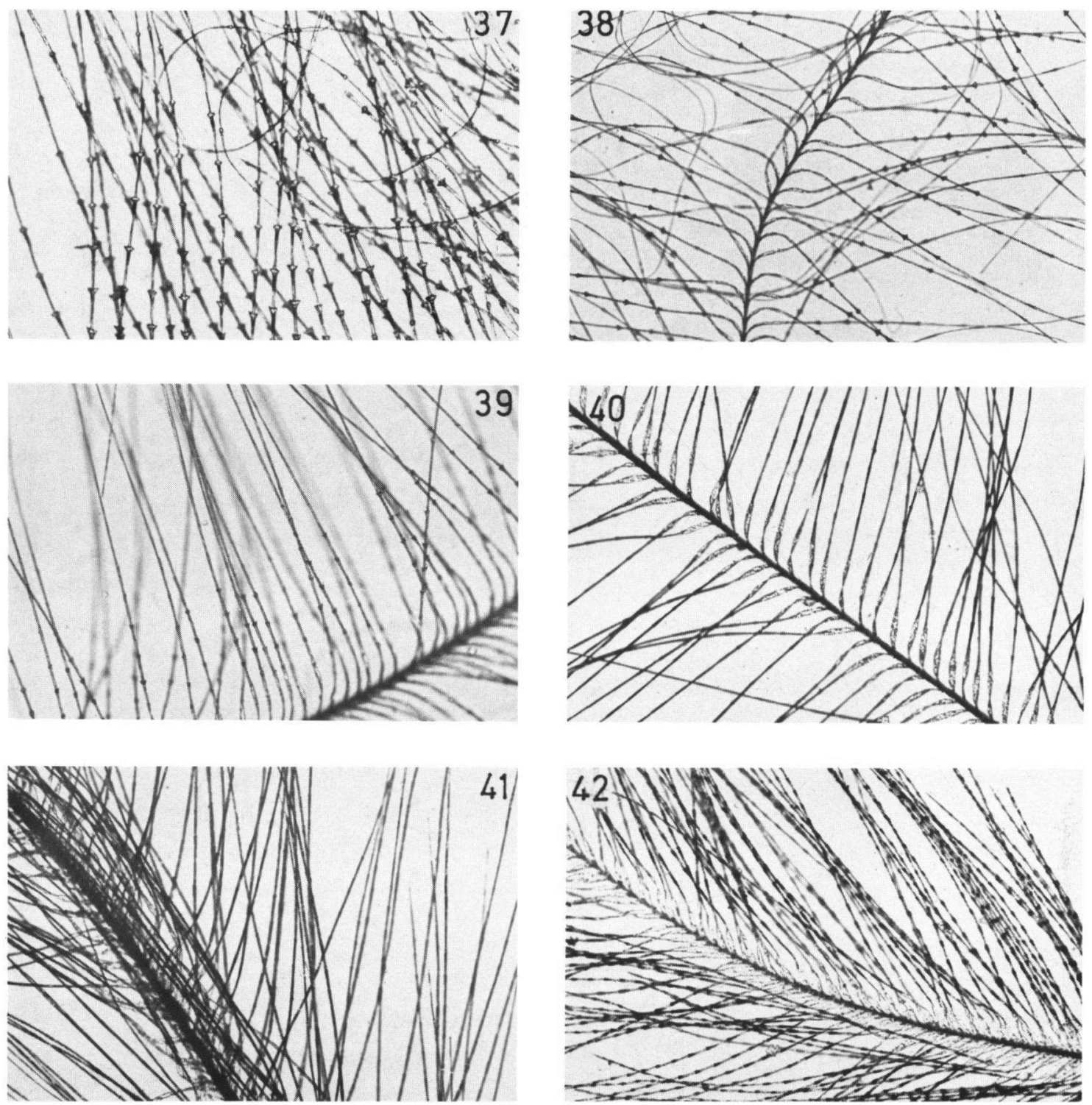

Fig. 37. Great Spotted Cuckoo Clamator glandarius; breast feather $(105 \times)$

Fig. 38. Barn Owl Tyto alba; neck feather $(85 \times)$.

Fig. 39. Snowy Owl Nyctea scandiaca; upper wing covert $(85 x)$.

Fig. 40. Red-necked Nightjar Caprimulgus ruficollis; breast feather $(85 \times)$.

Fig. 41. Swift Apus apus; breast feather $(85 \times)$.

Fig. 42. Kingfisher Alcedo atthis; breast feather $(85 \times)$.

division into nodes and internodes becomes visible. The nodes possess minute prongs, but nodes or prongs are very difficult to count. Both nodes and internodes are partly pigmented. No villi at the basal cells.
20. Coracilformes (figs. $42-43$; table XVI)

Four species from four families (Alcedinidae, Meropidae, Coraciidae, and Upupidae) have been examined. Range of weights 23-183 $\mathrm{g}$. 

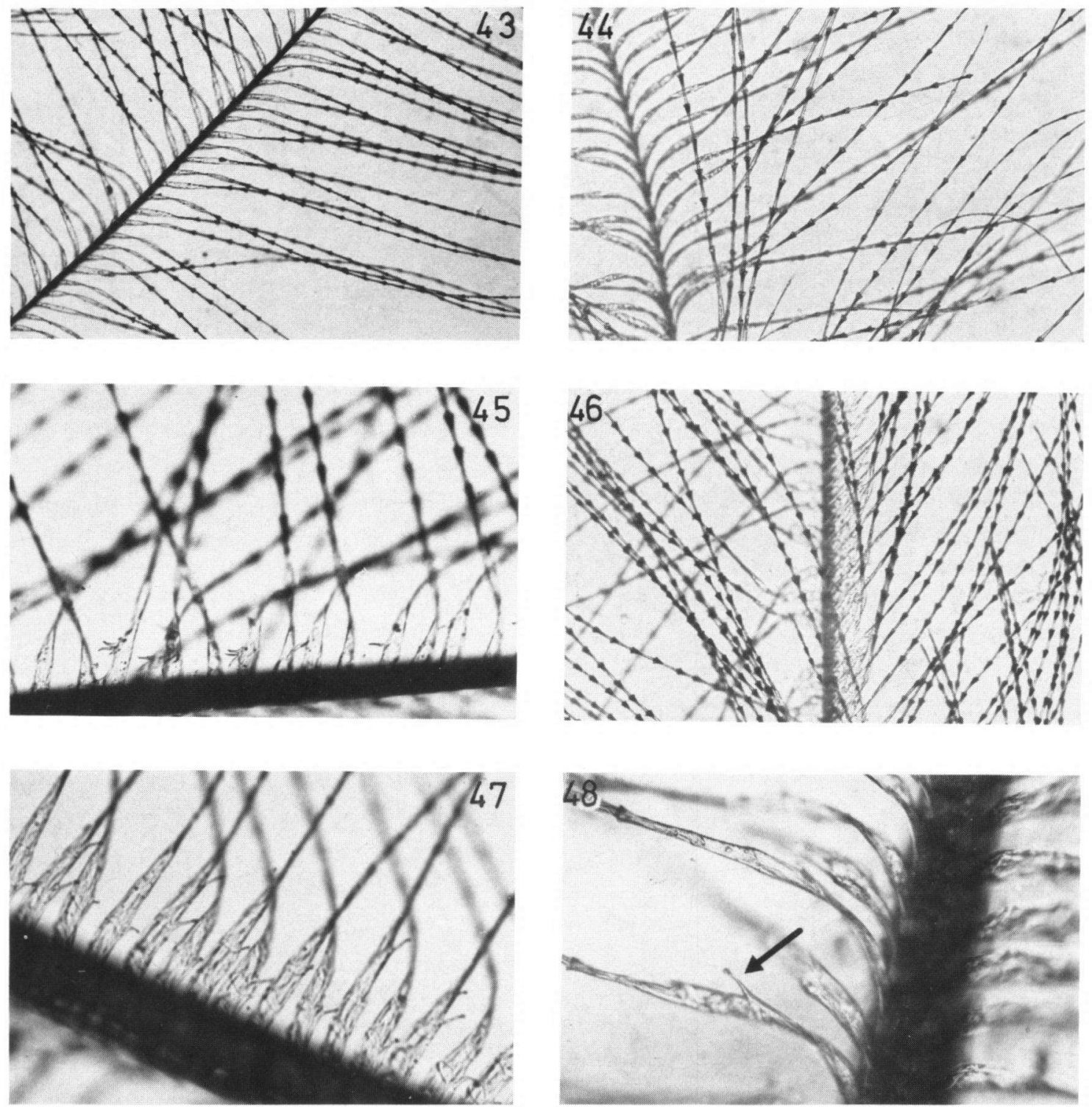

Fig. 43. Hoopoe Upupa epops; breast feather $(85 \times)$.

Fig. 44. Black Woodpecker Dryocopus martius; belly feather $(105 \times)$.

Fig. 45. Lesser Spotted Woodpecker Dendrocopos minor; breast feather $(165 \times)$. Curved and scimitar-shaped villi at the basal cells.

Fig. 46. Skylark Alauda arvensis; breast feather $(105 \times)$.

Fig. 47. Hooded Crow Corvus corone cornix; breast feather $(205 \times)$. Villi at the basal cells.

Fig. 48. Hooded Crow Corvus corone cornix; breast feather $(325 \times)$. Villus at basal cell (arrow).

Description. - The barbules are of medium length $(0.8-2.9 \mathrm{~mm})$ and they are clearly divided into pigmented nodes (14-32 per $\mathrm{mm}$ ) and unpigmented internodes. The nodes slightly decrease in size towards the tips of the barbules. Among the four species examined, a tendency seems to exist that larger birds possess fewer nodes per $\mathrm{mm}$ than smaller ones. No villi at the basal cells. 


\section{TABLE XVI}

Body weight (in $\mathrm{g}$ ), length of barbules (in $\mathrm{mm}$ ), and number of nodes (per mm barbule) in Coraciiformes.

\begin{tabular}{llccc}
\hline Species & & $\begin{array}{c}\text { body } \\
\text { weight }\end{array}$ & $\begin{array}{c}\text { barbule } \\
\text { length }\end{array}$ & $\begin{array}{c}N \text { of } \\
\text { nodes }\end{array}$ \\
\hline Alcedo atthis & Kingfisher & $23-46$ & $0.8-1.6$ & $21-32$ \\
Merops apiaster & Bee-eater & $37-60$ & $0.9-1.4$ & $21-26$ \\
Coracias garrulus & Roller & $107-183$ & $1.0-1.8$ & $14-24$ \\
Upupa epops & Hoopoe & $41-91$ & $1.6-2.9$ & $19-24$ \\
\hline
\end{tabular}

\section{Piciformes (figs. $44-45$; table XVII)}

Eight species of the family Picidae have been examined. Range of weights 23-317 g.

Description. - The barbules are of medium length $(0.6-2.5 \mathrm{~mm})$ and along their entire length they are clearly divided into pigmented nodes (21-39 per $\mathrm{mm}$ ) and unpigmented internodes. Only towards the tip the nodes slightly decrease in size. There is a tendency that larger birds possess fewer nodes per $\mathrm{mm}$ than smaller birds. At the basal cells curved or scimitarshaped villi are present which usually are pointing in the direction of the barb. The length of these villi ranges from 0.02 to $0.22 \mathrm{~mm}$.

\section{TABLE XVII}

Body weight (in $\mathrm{g}$ ), length of barbules (in $\mathrm{mm}$ ), and number of nodes (per mm barbule) in Piciformes.

\begin{tabular}{|c|c|c|c|c|}
\hline Species & & $\begin{array}{c}\text { body } \\
\text { weight }\end{array}$ & $\begin{array}{c}\text { barbule } \\
\text { length }\end{array}$ & $\begin{array}{c}N \text { of } \\
\text { nodes }\end{array}$ \\
\hline Jynx torquilla & Wryneck & 23-72 & $1.0-1.7$ & $31-36$ \\
\hline \multirow[t]{2}{*}{ Picus canus } & Grey-headed & & & \\
\hline & Woodpecker & $98-162$ & $0.9-1.5$ & $29-36$ \\
\hline P. viridis & Green Woodpecker & $101-250$ & $1.0-2.1$ & $27-36$ \\
\hline Dryocopus martius & Black Woodpecker & $201-317$ & $1.0-2.3$ & $21-31$ \\
\hline \multirow[t]{2}{*}{ Dendrocopos major } & Great Spotted & & & \\
\hline & Woodpecker & $53-110$ & $0.8-2.5$ & $24-30$ \\
\hline \multirow[t]{2}{*}{ D. medius } & Middle Spotted & & & \\
\hline & Woodpecker & $54-85$ & $1.0-1.9$ & $27-36$ \\
\hline \multirow[t]{2}{*}{ D. minor } & Lesser Spotted & & & \\
\hline & Woodpecker & $14-25$ & $0.6-1.2$ & $33-39$ \\
\hline Picoides & Three-toed & & & \\
\hline tridactylus & Woodpecker & $51-80$ & $0.8-1.7$ & 24-35 \\
\hline
\end{tabular}

\section{Passeriformes (figs. 46-48; table XVIII)}

This order contains nearly half of the known species of birds. It is divided into several suborders, of which in Europe only the largest (Oscines) is found. Some 100 species have been examined, belonging to 22 families. Range of weights 4-1560 g.

Description. - The barbules are of medium length $(0.5-3.3 \mathrm{~mm}$, but usually shorter than 2 $\mathrm{mm})$. They are clearly subdivided into enlarged and pigmented nodes (16-55 per $\mathrm{mm}$ ) and unpigmented internodes. The longest barbules are found in the families Turdidae (0.5-3.3 $\mathrm{mm})$, Corvidae $(0.6-2.7 \mathrm{~mm})$, and Alaudidae (0.6-2.2 $\mathrm{mm})$; in the remaining families they range from $0.5-1.6 \mathrm{~mm}$. At the basal cells villi are present, which differ in shape from those found in Piciformes by being blunt, knobbed, or finger-like, instead of recurved or sharply pointed.

\section{TABLE XVIII}

Body weight (in $\mathrm{g}$ ), length of barbules (in $\mathrm{mm}$ ), and number of nodes (per mm barbule) in Passeriformes.

\begin{tabular}{|c|c|c|c|c|}
\hline Species & & $\begin{array}{c}\text { body } \\
\text { weight }\end{array}$ & $\begin{array}{l}\text { barbule } \\
\text { length }\end{array}$ & $\begin{array}{l}N \text { of } \\
\text { nodes }\end{array}$ \\
\hline \multicolumn{5}{|l|}{ Melanocorypha } \\
\hline calandra & Calandra Lark & $55-63$ & $0.8 \cdot 1.7$ & $30-35$ \\
\hline Galerida cristata & Crested Lark & 31.49 & $0.8-2.2$ & $29-40$ \\
\hline Lullula arborea & Wood Lark & $20-40$ & $0.7-1.7$ & $28 \cdot 42$ \\
\hline Alauda arvensis & Skylark & $23-54$ & $0.7-1.6$ & $28-40$ \\
\hline Eremophila alpestris & Shore Lark & $27-46$ & $0.6-1.4$ & $31-37$ \\
\hline Riparia riparia & Sand Martin & $9-19$ & $0.6-1.1$ & $28-36$ \\
\hline Hirundo rustica & Swallow & $11-28$ & $0.6-1.2$ & $27-35$ \\
\hline Delichon urbica & House Martin & $10-28$ & $0.8-1.5$ & $27-32$ \\
\hline Anthus campesiris & Tawny Pipit & $16-27$ & $0.5-1.3$ & $26-35$ \\
\hline A. trivialis & Tree Pipit & $15-28$ & $0.5-1.1$ & $33-41$ \\
\hline A. pratensis & Meadow Pipit & $10-25$ & $0.5-1.0$ & 38.46 \\
\hline A. spinoletta & Water Pipit & $16-31$ & $0.6-1.1$ & $31-42$ \\
\hline Motacilla flava & Yellow Wagtail & $11-26$ & $0.7-1.4$ & $29 \cdot 38$ \\
\hline M. cinerea & Grey Wagtail & $14-25$ & $0.6-1.3$ & $29-38$ \\
\hline M. alba & White Wagtail & $15-30$ & $0.5-1.0$ & $36-42$ \\
\hline Bombycilla garrulus & Waxwing & $40-83$ & $0.7-1.3$ & $29-40$ \\
\hline Cinclus cinclus & Dipper & $49-100$ & $0.6-1.3$ & $26-34$ \\
\hline \multicolumn{5}{|l|}{ Troglodytes } \\
\hline troglodyles & Wren & $4-14$ & $0.6-1.4$ & $38-53$ \\
\hline Prunella modularis & Dunnock & $13-26$ & $0.8-1.7$ & $34-43$ \\
\hline \multicolumn{4}{|l|}{ Luscinia } & 30.44 \\
\hline megarhynchos & Nightingale & $12-27$ & $0.6-1.3$ & $30-43$ \\
\hline Phoenicurus ochrures & Black Redstart & 13-19 & $0.5-1.3$ & 34.45 \\
\hline Saxicola rubetra & Whinchat & $13-24$ & $0.5-1.2$ & $34-42$ \\
\hline$S$. torquata & Stonechat & $12-19$ & $0.5-1.3$ & 33.40 \\
\hline Oenanthe oenanthe & Wheatear & $14-41$ & $0.7-1.2$ & $34-43$ \\
\hline Zoothera dauma & White's Thrush & $100-190$ & $1.0-3.3$ & $22-33$ \\
\hline Turdus torquatus & Ring Ouzel & $83-138$ & $0.9-2.7$ & $20-31$ \\
\hline$T$. merula & Blackbird & $73-135$ & $1.0-1.9$ & $30-41$ \\
\hline T. pilaris & Fieldfare & $52-146$ & $0.6-2.2$ & $24-34$ \\
\hline T. philomelos & Song Thrush & $51-107$ & $1.0-2.6$ & $24-35$ \\
\hline$T$. iliacus & Redwing & $38-88$ & $0.8-1.7$ & $27-34$ \\
\hline T. viscivorus & Mistle Thrush & $95 \cdot 167$ & $1.1-3.0$ & $16-31$ \\
\hline Cettia cetti & Cetti's Warbler & $10-18$ & $0.5-1.1$ & $41-55$ \\
\hline
\end{tabular}


TABLE XVIII (continuation)

\begin{tabular}{|c|c|c|c|c|}
\hline Species & & $\begin{array}{l}\text { body } \\
\text { weight }\end{array}$ & $\begin{array}{l}\text { barbule } \\
\text { length }\end{array}$ & $\begin{array}{c}N \text { of } \\
\text { nodes }\end{array}$ \\
\hline \multirow[t]{2}{*}{ Locustella naevia } & Grasshopper & & & \\
\hline & Warbler & $11-16$ & $0.6-1.3$ & $35-44$ \\
\hline L. luscinioides & Savi's Warbler & $12-26$ & $0.7-1.6$ & $28-35$ \\
\hline \multicolumn{5}{|l|}{ Acrocephalus } \\
\hline palustris & Marsh Warbler & $9-17$ & $0.5-1.0$ & $37-46$ \\
\hline A. schoenobaenus & Sedge Warbler & $8-18$ & $0.5-1.3$ & $36-43$ \\
\hline \multirow[t]{2}{*}{ A. arundinaceus } & Great Reed & & & \\
\hline & Warbler & $22-53$ & $0.7-1.3$ & $32-42$ \\
\hline Hippolais icterina & Icterine Warbler & $8-16$ & $0.6-1.2$ & $31-41$ \\
\hline Sylvia nisoria & Barred Warbler & $19-30$ & $0.7-1.3$ & $27-42$ \\
\hline S. curruca & Lesser Whitethroat & $9-21$ & $0.6-1.2$ & $34-47$ \\
\hline S. communis & Whitethroat & $8-23$ & $0.5-1.3$ & $33-46$ \\
\hline S. borin & Garden Warbler & $12-28$ & $0.5-1.2$ & $35-46$ \\
\hline S. atricapilla & Blackcap & $11-27$ & $0.5-1.4$ & $37-45$ \\
\hline Phylloscopus & Yellow-browed & & & \\
\hline inornatus & Warbler & $4-8$ & $0.6-1.1$ & $38-45$ \\
\hline P. sibilatrix & Wood Warbler & $6-14$ & $0.5-1.0$ & $35-45$ \\
\hline P. collybita & Chiffchaff & $5-11$ & $0.5-0.9$ & $36-46$ \\
\hline P. trochilus & Willow Warbler & $5-13$ & $0.5-1.0$ & $39-50$ \\
\hline Regulus regulus & Goldcrest & $4-7$ & $0.6-1.1$ & $40-51$ \\
\hline$R$. ignicapillus & Firecrest & $4-9$ & $0.5-1.0$ & $38-49$ \\
\hline Muscicapa striata & Spotted Flycatcher & $10-20$ & $0.6-1.2$ & $34-44$ \\
\hline \multirow[t]{2}{*}{ Ficedula parva } & Red-breasted & & & \\
\hline & Flycatcher & $7-14$ & $0.5-1.0$ & $40-50$ \\
\hline F. hypoleuca & Pied Flycatcher & $9-19$ & $0.5-1.1$ & $32-46$ \\
\hline Panurus biarmicus & Bearded Tit & $12-18$ & $0.5-1.2$ & $38-46$ \\
\hline Aegithalos caudatus & Long-tailed Tit & $5-11$ & $0.5-1.2$ & $40-49$ \\
\hline Parus palustris & Marsh Tit & $7-14$ & $0.6-1.5$ & $34-44$ \\
\hline P. montanus & Willow Tit & $7-12$ & $0.5-1.0$ & $36-48$ \\
\hline P. cristatus & Crested Tit & $8-13$ & $0.6-1.1$ & $44-53$ \\
\hline$P$. ater & Coal Tit & $7-16$ & $0.6-1.1$ & $39-52$ \\
\hline$P$. cactuleus & Blue Tit & $9-16$ & $0.6-1.1$ & $43-52$ \\
\hline P. major & Great Tit & $14-22$ & $0.6-1.2$ & $38-47$ \\
\hline Sitta europaea & Nuthatch & $17-28$ & $0.6-1.1$ & $33-43$ \\
\hline Certhia & Short-toed & & & \\
\hline brachydactyla & Treecreeper & $7-14$ & $0.5-1.3$ & $37-50$ \\
\hline Oriolus oriolus & Golden Oriole & $52-96$ & $0.7-1.6$ & $21-31$ \\
\hline Lanius collurio & Red-backed Shrike & $23-38$ & $0.9-1.6$ & $29-35$ \\
\hline L. excubitor & Great Grey Shrike & $31-81$ & $0.9-1.5$ & $27-34$ \\
\hline L. senator & Woodchat Shrike & $21-45$ & $0.7-1.4$ & $26-36$ \\
\hline Garrulus glandarius & Jay & $121-199$ & $1.2-2.5$ & $25-33$ \\
\hline Pica pica & Magpie & $131-300$ & $0.6-1.9$ & $27-39$ \\
\hline \multicolumn{5}{|l|}{ Nucifraga } \\
\hline caryocatactes & Nutcracker & $110-200$ & $0.8-1.4$ & $27-34$ \\
\hline Corous monedula & Jackdaw & $123-281$ & $0.8-1.6$ & $28-40$ \\
\hline C. frugilegus & Rook & 225-595 & $1.0-2.0$ & $25-30$ \\
\hline C. corone corone & Carrion Crow & $322-695$ & $1.0-2.4$ & $23-34$ \\
\hline C. c. cornix & Hooded Crow & $440-611$ & $0.9-2.6$ & $26-36$ \\
\hline C. albus & Pied Crow & 474-612 & $0.8-2.1$ & $21-29$ \\
\hline C. corax & Raven & $798-1560$ & $1.0-2.2$ & $21-29$ \\
\hline Stumus vulgaris & Starling & 49-122 & $0.6-1.3$ & $31-41$ \\
\hline Passer domesticus & House Sparrow & $19-37$ & $0.9-1.6$ & $28-38$ \\
\hline P. montanus & Tree Sparrow & $15-29$ & $0.6-1.3$ & $32-40$ \\
\hline Fringilla coelebs & Chaffinch & $15-39$ & $0.5-1.4$ & $33-44$ \\
\hline F. montifringilla & Brambling & $15-37$ & $0.6-1.2$ & $35-43$ \\
\hline Serinus serinus & Serin & $9 \cdot 14$ & $0.6-1.1$ & $34-43$ \\
\hline$S$. canaria & Canary & $8-17$ & $0.5-1.0$ & $42 \cdot 52$ \\
\hline Carduelis chloris & Greenfinch & $20-37$ & $0.7-1.1$ & $35-45$ \\
\hline C. carduelis & Goldfinch & $12-22$ & $0.6-1.2$ & $36-46$ \\
\hline C. cannabina & Linnet & $16-24$ & $0.7-1.0$ & $35-44$ \\
\hline C. flavirostris & Twite & $13-21$ & $0.7-1.4$ & $35-43$ \\
\hline C. flammea & Common Redpoll & $9-23$ & $0.7-1.4$ & $43-52$ \\
\hline Loxia curvirostra & Crossbill & $24-48$ & $0.7-1.3$ & $35-44$ \\
\hline Pyrrhula pyrrhula & Bullfinch & $16-36$ & $0.5-1.4$ & $40-49$ \\
\hline C. coccothrausles & Hawfinch & $41-70$ & $0.6-1.2$ & $28-39$ \\
\hline Calcarius lapponicus & Lapland Bunting & $16-36$ & $0.6-1.1$ & $38-47$ \\
\hline
\end{tabular}

TABLE XVIII (continuation)

\begin{tabular}{llccc}
\hline Species & & $\begin{array}{c}\text { body } \\
\text { weight }\end{array}$ & $\begin{array}{c}\text { barbule } \\
\text { length }\end{array}$ & $\begin{array}{c}N \text { of } \\
\text { nodes }\end{array}$ \\
\hline Plectrophenax nivalis & Snow Bunting & $22-50$ & $0.7-1.1$ & $36-50$ \\
Emberiza cilrinella & Yellowhammer & $18-40$ & $0.7-1.2$ & $32-42$ \\
$E$. hortulana & Ortolan Bunting & $15-33$ & $0.5-1.2$ & $29-38$ \\
$E$. pusilla & Little Bunting & $13-16$ & $0.5-1.3$ & $29-36$ \\
E. schoeniclus & Reed Bunting & $15-28$ & $0.7-1.4$ & $37-46$ \\
Miliaria calandra & Corn Bunting & $34-64$ & $0.6-1.3$ & $36-46$ \\
\hline
\end{tabular}

\section{IDENTIFICATION KEY}

It is strongly recommended to use this key only after studying the previous description of the characters of the 22 orders of birds examined. The key will only permit identification if some coherent barbs are present in the sample. When only detached barbules are found, the identification procedure will have to be stopped if comparisons between barbules must be made. In the case that only a very small sample is available, it may not always be certain that downy barbules are present. It must be kept in mind that barbules originating from the pennaceous portion of the feather cannot be identified with the help of this key. Some characters are diagnostic for certain groups when only one example is found (such as the occurrence of multiple nodes in Galliformes), but in other cases (such as the occurrence of villi at the basal cells in Piciformes and Passeriformes) it is recommended to look for several examples to make sure that no artifacts interfere with a correct identification.

1. Barbules possess prongs ......................... 2

- Barbules lack prongs .............................. 3

2. Barbules possess triangular (heart-shaped) nodes distally ................................................. 4

- Barbules without triangular nodes distally .... 5

3. Barbules possess triangular (heart-shaped) nodes distally ............................................. 4

- Barbules without triangular nodes distally ..... 12

4. Barbules with triangular (heart-shaped) nodes distally: ANSERIFORMES

- nodes along $<40 \%$ of barbule: Ducks

- nodes along $40-60 \%$ of barbule: GEESE

- nodes along $>60 \%$ of barbule: swans

5. Prongs longer than adjacent internodes: Sulidae

- Prongs shorter than adjacent internodes 
6. At low magnification $(50 x)$ barbules clearly subdivided into enlarged nodes and internodes .... 7

- At low magnification $(50 x)$ nodes very difficult to discern

7. In most barbules (basalmost of barb) nodes rapidly decrease in size over 2-6 basal internodes ...... 8

- No decrease in size of nodes apparent: Procellarifformes, Phaethontidae

8. Barbule length $>1.5 \mathrm{~mm}$ and nodes $<18$ per mm: Pteroclidiformes

- Barbule length $<1.5 \mathrm{~mm}$ and nodes $>15$ per $\mathrm{mm}$ : Laridae, Sternidae

9. Barbule length $>3 \mathrm{~mm}$, prongs usually asymmetrical: ACCIPITRIFORMES

- Barbule length $<3 \mathrm{~mm}$ 10

10. Prongs only at one side of the majority of barbules: Podicipediformes

- Prongs at both sides of barbules

11. Barbule length $>1.7 \mathrm{~mm}$ : Ciconitdae, Ardeidae, Gruidae

- Barbule length $<1.7 \mathrm{~mm}$ : Gaviiformes, Pelecanidae, Fregatidae, Phalagrocoracidae, Threskiornithidae, Phoenicopteriformes, Haematopodidae, Recurvirostridae, Stercoraritdae, Algidae

12. At low magnification $(50 x)$ barbules clearly subdivided by enlarged nodes and internodes ..... 17

- At low magnification $(50 \times)$ no conspicuous subdivision into nodes and internodes .................. 13

13. At low magnification $(50 x)$ barbules visible as strongly pigmented threads ..................... 14

- Barbules filamentous and not strongly pigmented

14. Barbule length $>1.7 \mathrm{~mm}$ :

Caprimulgiformes

- Barbule length $<1.7 \mathrm{~mm}$ : APODIFormes

15. Barbule length $>1.7 \mathrm{~mm}$

- Barbule length $<1.7 \mathrm{~mm}$ : HaEmatopodidae, Recurvirostridae

16. At higher magnification $(150 \times)$, at the basal part of the barbules some enlarged nodes are visible which decrease in size over a short distance: ACCIPITRIFORMES, OtIDIDAE

- At higher magnification $(150 x)$ a subdivision of the barbules is visible, but proximally the nodes are not more enlarged than elsewhere:

Ciconitrormes

17. Villi present at the basal cells 18

- Villi absent at the basal cells 19

18. Villi recurved and sharply pointed: Piciformes

- Villi blunt, knobbed, or finger-like: Passeriformes

19. Multiple nodes present: Galliformes

- Multiple nodes absent
20. Nodes along entire length of barbules, not plate-like in shape ........................................... 21

- Nodes flattened and plate-like in shape; only at most basal barbules reaching tip of barbule, but usually not present along entire length (the remaining part being smoothly filamentous):

Columbiformes

21. Pigment located in spots just proximal of globular nodes and barbules very long and slender:

Cuculiformes

- Pigment located in nodes ....................... 22

22. In the basalmost barbules nodes abruptly decrease in size over short distance ......................... 23

- No reduction in size of basalmost nodes ........ 24

23. Barbule length $>1.7 \mathrm{~mm}$ (barbules often in clews), most nodes elongate in shape:

STRIGIFORMES

- Barbule length $<1.7 \mathrm{~mm}$ and reduction in size of nodes more pronounced in one of the two vanules: Rallidae

24. Both pigmented and unpigmented nodes occur within one feather or even in one barbule ............. 25

- Barbules uniform in pigmentation ............... 26

25. Barbules slender and wavy, internodes kinky: Psittaciformes

- Barbules not slender and wavy, short internodes not kinky:

Charadriddae, Numenius, Calidris, Tringa, Limosa, Arenaria, Philomachus

26. Barbules very slender and wavy (often in clews), nodes small and rounded:

FaLConiformes

- Barbules straight, nodes not rounded:

Coracifformes, Turnicidae, Glareolidae, Scolopax, Gallinago, Lymnocryptes, Phalaropus

\section{CONCLUSIONS}

Using the structure of the downy barbules of feathers one can usually establish the order to which a given bird belongs. The described characters proved to be very uniform within monophyletic taxa, but show striking differences between birds that occupy comparable habitats (e.g. Gaviiformes, Podicipediformes, Anseriformes, Rallidae, and Alcidae), leading to the conclusion that these characters are not highly adaptive.

In several groups the distribution of nodal structures along the barbules is related to the size of the bird. Within the Falconidae, Galliformes, Rallidae, Laridae, Sternidae, Psittaciformes, Strigiformes, Coraciiformes, 
Piciformes, and Passeriformes, a tendency has been found that larger birds possess fewer nodes per $\mathrm{mm}$ barbule than smaller birds.

\section{DISCUSSION}

Microscopic identification of feathers is based on the observation that the fine structures of feathers from each species of bird differ just as do other characters. The more closely two species are related, the more alike the feather structures are, and conversely. It seems that the complexity of feather structures generally follows the taxonomic order, although the exact value of this set of characters for avian taxonomy remains to be evaluated. It is evident that some of the described characters unite several orders, whereas other characters separate families that are usually grouped within one (assumed) order. Groups that attract special attention are the Falconidae and the Rallidae. Their downy barbules have microstructures that are totally different from their alledged relatives, the Accipitriformes and the remaining Gruiformes, respectively.

The identification method described in this paper has been extensively applied to the study of collisions between birds and aircraft (bird strikes). In combination with the method of comparing feathers with bird skins, it usually leads to identification at order-, family-, or species-level. The level of identification is further influenced by the presence or absence of additional information, such as time of the season, time of the day, height, and location. Applied to bird strike analysis, this method is a major improvement of existing methods of identification. In $97 \%$ of all cases $(N=658)$ the order could be established (in the remaining $3 \%$ a bird strike usually could be confirmed, but the material was not sufficient for further identification), in $47 \%$ of the cases the species could be established (Brom, 1984). For bird strike analysis it is very useful that in several groups of birds a tendency exists that larger birds have fewer nodes per $\mathrm{mm}$ of barbule than smaller birds. In this way an indication of the weight of the bird can be obtained without exactly knowing the actual species involved. This is important as weight is a key factor in the analysis of bird strikes (Buurma, 1984). For example, within the Passeriformes crows can always be distinguished from small songbirds. In a similar way, a distinction can be made between ducks, geese, and swans in the family Anatidae.

In contrast to mammals, the phylogeny of birds is still very imperfectly understood (see e.g. the discussion between Cracraft, 1981, and Olson, 1982). Owing to the constraints of flight, the general morphology of birds is less diverse than that of mammals (discussed by Wyles et al., 1983). The application of the method of phylogenetic analysis is hindered by the difficulty in recognizing clearly character states that are either plesiomorphic or apomorphic.

Recently the amino-acid sequence of the eye lens protein $\alpha$-crystallin A was studied in 19 bird species, belonging to 14 orders (Stapel et al., 1984). This study provided new evidence that the Ratites are the sister-group of all other birds. However, the resolution of the method is insufficient to determine the relationships of most other orders.

Comparative studies on feather keratins carried out on solubilized S-carboxymethyl (SCM) proteins show that the patterns on polyacrylamide gel electrophoresis (PAGE) are complex and that they may contain taxonomic information. Comparison of these patterns for 45 genera belonging to the Anseriformes led to the production of a dendrogram of intraordinal relationships (Brush, 1976a, b). Some feather keratin monomers are species specific, whereas others are tissue specific and appear to be characteristic of various feather parts such as the vane or rachis, or are typically found in the pennaceous or downy portion of the feather (O'Donnell, 1973; O'Donnell \& Inglis, 1974; Fraser \& MacRae, 1976; Busch \& Brush, 1979).

Studies on the internal structure of shafts and barbs (by means of transverse sectioning) suggest that the cellular arrangements in medulla and cortex constitute a taxonomically important character: these configurations are con- 
stant within a species, differ from related species only in detail, and include a basic pattern common to all species of a family (Frank, 1939; Auber \& Appleyard, 1955; Auber \& Mason, 1955; Auber, 1957, 1959, 1964; Swales, 1970; Dyck, 1977).

A more detailed study of the ptilomorphology (both external and internal) might answer the questions (a) to what extent are feather characters adaptive, and (b) which characters are to be considered primitive and which are derived. These aspects of phylogenetic analysis will require a detailed comparative study which may lead to new data with a bearing on the relationships of the higher taxa of birds. The fact that the general structure of barbules often does not vary within entire orders or families makes these characters suitable for phylogenetic studies at higher levels. The value of this study will reside in the possibility to apply it as an independent test to the results of several recent studies that are mainly based on a molecular approach (e.g. Lewin, 1985; Sibley \& Ahlquist, 1986; Stapel, 1986).

\section{ACKNOWLEDGEMENTS}

The financial support by the Royal Netherlands Air Force is gratefully acknowledged. I wish to thank Dr. Jan Wattel (Curator of the Bird Department of the Zoölogisch Museum Amsterdam) for the opportunity to study material under his care and for his valuable suggestions, and Anthony James for editorial assistance. Mr. J. Zaagman kindly helped with the preparation of the illustrations.

\section{REFERENCES}

Altenburg, W., M. Engelmoer, R. Mes \& T. Piersma, 1982. Wintering waders on the Banc d'Arguin, Mauretania. Report of the Netherlands Ornithological Mauretanian Expedition 1980. Commun. Wadden Sea Working Group, 6: 1-283 (Stichting Veth tot steun aan Waddenonderzoek, Leiden).

Astier, J. F., 1982. Le régime alimentaire du Renard roux (Vulpes vulpes). Choix et expérimentation d'une méthode d'étude: 1-42, annexe [1-19] (mimeographed report, St. Ismier).

Auber, L., 1957. The structures producing "noniridescent" blue colour in bird feathers. Proc. zool. Soc. Lond., 129: 455-486.
- - 1959. The structure of feathers in Meropidae and its evolutionary significance. Int. Congr. Zool., 15: 452-455.

-, 1964 . The possible evolutionary significance of differences in feather structure between closely related Pittidae (Passeres: Mesomyodes). J. Linn. Soc., (Zool.), 45 (305): 245-250.

Auber, L. H. M. Appleyard, 1955. The structure of the feathers in Chlorophanes and Iridophanes (Coerebidae). Ibis, 97: 252-258.

Auber, L. M. V. Mason, 1955. Structurally coloured pattern marks on the inner webs of flight feathers. Ibis, 97: 259-265.

Bennike, O. \& J. Dyck, 1986. A subfossil Lapland Bunting Calcarius lapponicus feather from Vølvedal, North Greenland. Ornis scand., 17: 75-77.

Brom, T. G., 1980. Microscopic identification of featherremains after collisions between birds and aircraft: 189 (mimeographed report, Amsterdam).

-, 1984 . Microscopic identification of feathers in order to improve birdstrike statistics. In: M. J. HARRISON, S. A. Gauthreaux \& L. A. Abron-Robinson eds., Proceedings Wildlife Hazards to Aircraft Conference and Training Workshop, Charleston, S.C.: 107-119 (National Technical Information Service, Springfield, Virginia).

-, 1986. Identification of bird remains for bird strike analysis: a literature synopsis. 18th Meeting Bird Strike Committee Europe, Copenhagen, Working Paper, 23: 1-7.

Brom, T. G. \& L. S. BuUrma, 1979. The quality of identification: a microscopic key to the determination of feather-remains. 14th Meeting Bird Strike Committee Europe, The Hague, Working Paper, 19: [1-6].

- \& \& - 1981. Microscopische herkenning van veerresten: hulpmiddel bij de analyse van aanvaringen tussen vliegtuigen en vogels. Het Vogeljaar, 29 (1): 9-17.

Brough, T., 1983. Average weights of birds: 1-131 (Aviation Bird Unit, Worplesdon Laboratory, Guildford).

Brush, A. H., 1976a. Some taxonomic and evolutionary aspects of feather proteins. In: H. J. FriTH \& J. H. Calaby eds., Proc. 16th int. Orn. Congr.: 402-413 (Australian Academy of Sciences, Canberra).

-, $1976 \mathrm{~b}$. Waterfowl feather proteins: analysis of use in taxonomic studies. J. Zool., Lond., 179 (4): 467-498.

Busch, N. E. A. H. Brush, 1979. Avian feather keratins: molecular aspects of structural heterogeneity. J. exp. Zool., 210: 39-48.

BuUrma, L. S., 1983. Increasing birdstrike rates and improved birdstrike analysis of the Royal Netherlands Air Force. Conference on Aerospace Transparent Materials and Enclosures, Scottsdale, Arizona, 11-14 July 1983, Working Paper: 1-25.

-, 1984 . Key factors determining birdstrike and risks. Int. J. Aviation Safety, 2 (1): 91-107. 
Buurma, L. S. \& T. G. Brom, 1979. The quality of identification: its effects on birdstrike statistics. 14th Meeting Bird Strike Committee Europe, The Hague, Working Paper, 20: [1-8].

- $\quad$ - 1980 . Harde feiten over zachte veren. Veilig Vliegen, 27 (1): 9-13.

- $~-~-, 1981$. Harde feiten over zachte veren. Technisch Informatie Programma (KLM), 9 (92): 14-16.

Buurma, L. S., A. Dekker \& T. G. Brom, 1984. On the spatial and temporal distribution of bird species involved in RNLAF birdstrikes. 17th Meeting Bird Strike Committee Europe, Rome, Working Paper, 14: 1-15.

Chandler, A. C., 1916. A study of the structure of feathers, with reference to their taxonomic significance. Univ. Calif. Publs. Zool., 13 (11): 243-446.

Cracraft, J., 1981. Toward a phylogenetic classification of the recent birds of the world (Class Aves). Auk, 98: 681-714.

Cramp, S. (ed.), 1985. The birds of the western Palearctic, 4: 1-960 (Oxford Univ. Press, Oxford/New York).

Cramp, S. K. E. L. Simmons (eds.), 1977, 1980, 1983. The birds of the western Palearctic, 1: 1-722; 2: 1695; 3: 1-913 (Oxford Univ. Press, Oxford etc.).

Davies, A., 1970. Micromorphology of feathers using the scanning electron microscope. J. forensic Sci. Soc., 10 (3): $165-174$.

DAY, M. G., 1966. Identification of hair and feather remains in the gut and faeces of stoats and weasels. J. Zool., Lond., 148: 201-217.

Deedrick, D. W. J. P. Mullery, 1981. Feathers are not lightweight evidence. FBI Law Enforcement Bull., Sept. 1981: 22-23.

Dyck, J., 1977. Feather ultrastructure of Pesquet's Parrot Psittrichas fulgidus. Ibis, 119: 364-366.

Frank, F., 1939. Die Färbung der Vogelfeder durch Pigment und Struktur. J. Orn., 87 (3): 426-524, Taf. I-VIII.

Fraser, R. D. B. \& T. P. MacRae, 1976. The molecular structure of feather keratin. In: H. J. Frith \& J. H. Calaby eds., Proc. 16th int. Orn. Congr.: 443-451 (Australian Academy of Sciences, Canberra).

Gilbert, F. F. E. G. Nancekivell, 1982. Food habits of mink (Mustela vison) and otter (Lutra canadensis) in northeastern Alberta. Can. J. Zool., 60 (6): 1282-1288.
Hargrave, L. L., 1965. Identification of feather fragments by microstudies. American Antiquity, 31 (2): 202-205.

LAHAM, Q. N., 1967. Report on aircraft turbine engine birdstrike investigations. National Research Council of Canada, Associate Committee on bird hazards to aircraft, Field Note, 43: 1-27.

Lewin, R., 1985. Molecules vs. morphology: Of mice and men. Science, 229 (4715): 743-745.

Messinger, N. G., 1965. Methods used for identification of feather remains from Wetherill Mesa. American Antiquity, 31 (2): 206-215.

O'Donnell, I. J., 1973. The complete amino acid sequence of a feather keratin from Emu (Dromaius novae-hollandiae). Aust. J. biol. Sci., 26: 415-435.

O'Donnell, I. J. \& A. S. Inglis, 1974. Amino acid sequence of a feather keratin from Silver Gull (Larus novae-hollandiae) and comparison with one from Emu (Dromaius novae-hollandiae). Aust. J. biol. Sci., 27: 369-382.

Olsen, A. R., 1981. Distinguishing common foodcontaminating bat hairs from certain feather barbules. J. Assoc. Off: Anal. Chem., 64 (4): 786-791.

Olson, S. L., 1982. A critique of Cracraft's classification of birds. Auk, 99: 733-739.

Robertson, J., C. Harkin \& J. Govan, 1984. The identification of bird feathers. Scheme for feather identification. J. forensic Sci. Soc., 24: 85-98.

Sibley, C. G. J. E. AhlQuist, 1986. Reconstructing bird phylogeny by comparing DNA's. Scient. Am., 254 (2): 82-92.

StaPel, S. O., 1986. Crystallins and avian phylogeny: 1107 (Ph.D. Thesis, Univ. Nijmegen).

Stapel, S. O., J. A. M. Leunissen, M. Versteeg, J. WAttel \&. W. DE Jong, 1984. Ratites as oldest offshoot of avian stem - evidence from $\alpha$-crystallin A sequences. Nature, Lond., 311 (5983): 257-259.

Swales, M. K., 1970. A preliminary study on the application of the internal structure of feather barbs to avian taxonomy. Ostrich Suppl., 8: 55-66.

Voous, K. H., 1973. List of recent holarctic bird species. Non-passerines. Ibis, 115: 612-638.

- , 1977. List of recent holarctic bird species. Passerines. Ibis, 119: 223-250, 376-406.

Wyles, J. S., J. G. Kunkel \& A. G. Wilson, 1983. Birds, behavior, and anatomical evolution. Proc. natn. Acad. Sci. U.S.A., 80: 4394-4397. 